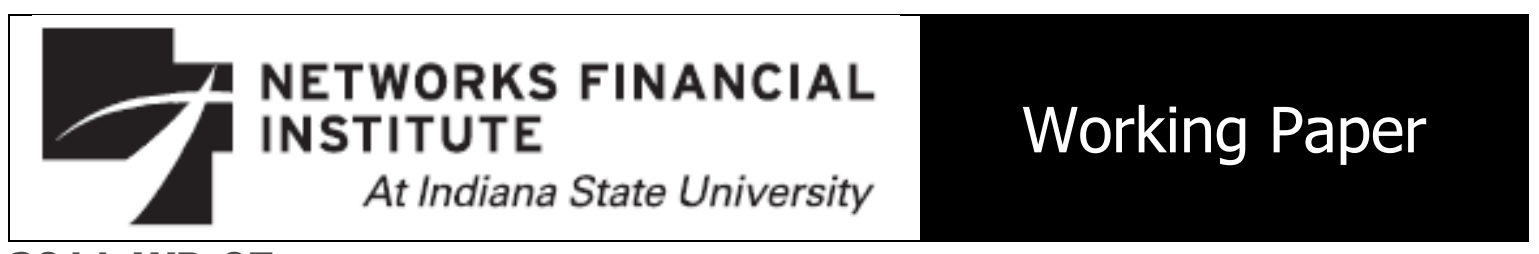

2011-WP-07

April 2011

\title{
The Impact of Portfolio Disclosure on Hedge Fund Performance, Fees and Flows
}

Zhen Shi

\begin{abstract}
This study investigates the impact of portfolio disclosure on hedge fund performance. Using a regression discontinuity design, I investigate the effect of the disclosure requirements that take effect when an investment company's assets exceed $\$ 100$ million; when that occurs, a fund is required by the U.S. Securities and Exchange Commission to submit form 13F disclosing its portfolio holdings. Consistent with the argument that portfolio disclosure reveals "trade secrets" and also raises front running costs thus harms the funds that disclose, I find that there is a drop in fund performance (about 4 percent annually) after a fund begins filing form $13 \mathrm{~F}$, as well as an increase in return correlations with other hedge funds in the same investment style. The drop in performance cannot be explained by a change in the assets under management or a mean reversion in returns. Consistent with the idea that funds with illiquid holdings tend to employ sequential trading strategies, which increase the likelihood of being taken advantage of by free riders and front runners, the drop in performance is more dramatic for funds that have more illiquid holdings. In addition, I find that the incentive fees paid to fund managers are 1 percent higher when portfolio disclosure is required, which supports the hypothesis that investors' monitoring of portfolio holdings disciplines adverse risktaking by fund managers and allows for higher convexity in the optimal compensation structure. Finally, there is a drop in flows into funds that file 13F, which suggests that hedge fund investors negatively value $13 \mathrm{~F}$ disclosure. Overall, this study suggests that the cost of portfolio disclosure is economically large. It contributes to the policy debate over what constitutes optimal disclosure.
\end{abstract}

About the Author: Zhen Shi is completing her Ph.D. in Finance at Arizona State University. She will join Georgia State University as an Assistant Professor in August 2011. Zhen Shi's primary research areas are investments, hedge funds, compensation, and behavioral finance. She has examined the issues related to portfolio disclosure for the loosely regulated hedge fund industry. Her current work in behavioral finance studies how behavioral biases affect trading decisions and asset prices. She has presented her research at the European Finance Association Annual Meeting in 2010 and the American Finance Association Annual Meeting in 2011. Zhen Shi received her B.E. in Environmental Engineering from Tsinghua University, China and M.S. degree in Environmental Engineering from Pennsylvania State University.

The views expressed are those of the individual author and do not necessarily reflect official positions of Networks Financial Institute. Please address questions regarding content to Zhen Shi at Zhen.Shi@asu.edu. Any errors or omissions are the responsibility of the author.

NFI working papers and other publications are available on NFI's website (www.networksfinancialinstitute.org). Click "Thought Leadership" and then "Publications/Papers." 


\section{The Impact of Portfolio Disclosure on Hedge Fund Performance, Fees and Flows}

\section{Introduction}

Determining the extent to which investment portfolios should be publicly disclosed is a basic challenge facing hedge fund industry participants and regulators. Portfolio disclosure is beneficial to the extent that it allows investors to make informed investment allocation decisions and reduces potential agency costs that can arise when managerial actions are more opaque. Portfolio disclosure, however, is costly if it reveals proprietary information and facilitates free-riding activities by others on a fund's profitable investments and trading strategies. ${ }^{1}$ In this study, I investigate the effect of the portfolio disclosure requirements that take effect when an investment company's assets exceed \$100 million; when that occurs, hedge fund and other institutional managers are required by the U.S. Securities and Exchange Commission (SEC) to file form 13F, reporting their quarterly holdings within 45 days after the end of each quarter. This discontinuous change in disclosure regimes around the $\$ 100$ million threshold allows for the use of a regression discontinuity approach and the identification of a causal effect of portfolio disclosure on hedge fund performance that is purged of potential endogeneity problems. The identifying assumption is that the function that relates fund size to performance does not have precisely the same jumps as the function that relates fund size to disclosure. This procedure is valid even if unobserved factors that affect performance (such as a fund manager's skills) are functionally related to fund size.

Using a complete sample of 4,024 hedge fund managers that report to TASS over the period of February 1977 to February 2010, among which 414 have filed Form 13F at least

\footnotetext{
${ }^{1}$ Frank, Poterba, Shackelford, and Shoven (2004) demonstrate that hypothetical "copycat" funds created by mimicking the portfolio holdings of actively managed mutual funds earn after expense returns that are indistinguishable from the copied funds.
} 
once, I find that fund performance is lower in the disclosure periods than in the nondisclosure periods. The results are robust to five performance measures, including raw returns, market model alpha, Fama-French three-factor alpha, Carhart four-factor alpha, and Fung-Hsieh seven-factor alpha. The cost of performance disclosure is economically large. For example, when measured by the Fama-French three-factor alpha, the performance is 4 percent lower (annually) during the disclosure periods. I also find that the drop in performance does not occur slowly over time; instead, it occurs in the form of a "sudden" drop in the first year after a fund files its first $13 \mathrm{~F}$ disclosure. This finding of a 'discontinuous' drop in performance along the time dimension lends strong support to the argument that the decreased performance is due to portfolio disclosure.

Using a regression discontinuity design where samples are narrowed to a small neighborhood around the $\$ 100$ million threshold, I find that there is a drop in fund performance that occurs in the form of a discontinuous 'jump' and that it cannot be explained by continuous changes in the assets under management when the regulatory regime switches from non-disclosure to disclosure. In addition, I find that there is no such discontinuous drop in performance for funds that also crossed the $\$ 100$ million threshold but were not required to file $13 \mathrm{~F}^{2}$ Furthermore, there is no drop in fund performance when funds crossed other thresholds (e.g., $\$ 80$ million or $\$ 120$ million). These results confirm that the drop in performance following disclosure is not due to change in size or mean reversion in returns.

In support of the hypothesis that the decreased performance in the periods of portfolio disclosure is due to free-riding activities by other fund managers, I find that the return correlations between disclosing funds and other hedge funds that are in the same investment

${ }^{2}$ The fact that these large funds are not required to file $13 \mathrm{~F}$ is because they hold non-13(f) securities, short positions, or securities that are less than 10,000 shares or with market value less than $\$ 200,000$. 
style are greater in the disclosure periods than in the non-disclosure periods. This finding supports the idea that other funds take positions more similar to disclosing funds after disclosing funds disclose their portfolio holdings or that incentives to pursue novel strategies diminish following disclosure.

I also investigate the extent to which the liquidity of portfolio holdings affects the cost of disclosure. In general, trades in illiquid securities result in larger price impacts than trades in liquid securities. In order to reduce the transaction cost due to price impact, fund managers tend to employ sequential trading strategies to accumulate or dispose of an illiquid position. However, the longer it takes to accumulate or dispose of a position, the higher the likelihood and greater the cost of being taken advantage of by frontrunners and free riders. Consistent with these observations, I find that the drop in performance is more dramatic for funds with illiquid holdings.

Disclosure is intended to improve monitoring and reduce agency problems. One of the main agency problems facing hedge fund investors is that managers may take on excessive risk, especially given the prevailing option-like "bonus" incentive fee. ${ }^{3}$ Under "bonus" incentive fees, hedge fund managers receive a fixed percentage of fund profit but are not penalized when they incur losses. Thus, hedge fund managers do not suffer any downside risk. Unlike the time series of past fund returns, which provide a very limited view of fund risk, ${ }^{4}$ portfolio disclosure allows investors to observe the holdings and assess the risk that

\footnotetext{
${ }^{3}$ Starks (1987) and Grinblatt and Titman (1989) show in theoretical models that managers have incentives to choose greater risks than the desired risk level by the clients under option like incentive fees. Coles, Daniel, and Naveen (2006) show empirically that higher sensitivity of CEO wealth to stock volatility (vega) implements riskier policy choices. Golec and Starks (2004) find that an exogenous change in incentive fees reduces mutual fund managers' risk taking. ${ }^{4}$ See Stulz (2007) for a discussion on "earthquake" risks that can't be detected from past performance.

${ }^{5}$ See Healy and Palepu (2001) for a review of empirical disclosure literature.
} 
they are exposed to. Their monitoring of portfolio holdings may discipline risk taking by fund managers and reduce the convexity of the incentive fees. Consistent with this argument that portfolio disclosure allows higher convexity in the optimal compensation structure, I find that incentive fees are 1 percent higher in the presence of portfolio disclosure, after controlling for other factors such as assets under management and age of the fund families.

Finally, whether hedge fund investors value $13 \mathrm{~F}$ portfolio disclosure is still an open question. While investors may prefer more disclosure for the increased transparency it affords, they may prefer less disclosure if it leads to lower fund performance. The value that investors attach to the $13 \mathrm{~F}$ disclosure can be measured by the fund flows in and out of the funds. I find that flows are lower in the periods of disclosure than in non-disclosure periods. The test for this controls for the change in flows that might be expected in response to other factors, such as changes in past performance (Berk and Green, 2004). My finding suggests that hedge fund investors place a negative value on $13 \mathrm{~F}$ portfolio disclosure.

This study is related to a broader literature on financial information disclosure. ${ }^{5}$ There are several advantages of using hedge funds as a laboratory to examine issues related to disclosure. First, the proprietary cost of disclosure is plausibly more important for hedge fund managers. Hedge funds are relatively unfettered in their ability to use leverage, derivatives, and short sales across several asset classes. This structure might attract talented managers with sophisticated trading strategies. Second, hedge funds often utilize lockup provisions and hold illiquid assets, practices that suggest they are also more likely to use dynamic trading strategies. Disclosure especially undermines the profitability of these strategies. Third, the extent of disclosure, firm performance, and the value investors attach to the disclosure policy can be directly and easily measured in the context of portfolio disclosure. In contrast, the difficulty of measuring the extent of disclosure has constrained 
research in the area of financial information disclosure (Healy and Palepu, 2001).

This study provides direct evidence that portfolio disclosure harms hedge fund performance and suggests that the cost of disclosure is economically large. This finding is supported by Aragon, Hertzel, and Shi (2009) and by Agarwal, Jiang, Tang, and Yang's (2009), who demonstrate that hedge fund managers request confidential treatment to delay 13F disclosure of their profitable ideas. This study is also in line with the finding of Ge and Zheng (2006) that past "winner" mutual funds that disclose less frequently outperform those that disclose more frequently.

This study is also the first to analyze the interactions between portfolio disclosure and compensation structure in the investment fund industry. A fund manager's adverse risktaking incentive is similar to the risk-shifting incentive of an equity holder to expropriate wealth from existing bondholders. My finding that incentive fees are higher in the presence of portfolio disclosure is similar to John, Mehran, and Qian's (2008) finding that the pay-forperformance sensitivity of CEO compensation increases with the intensity of outside monitoring of the firm's risk choice, though their focus is not on the convexity of the compensation.

The remainder of the paper is organized as follows. Section II describes the data. Section III discusses the methodology and empirical results. Section IV concludes.

\section{Data}

\subsection{Institutional Investment Managers and Form 13F}

Since 1978, all institutional investment managers (including hedge fund managers) who exercise investment discretion over $\$ 100$ million or more have been required by Section 13(f) of the Exchange Act to make quarterly disclosures of portfolio holdings to the SEC on 
form $13 \mathrm{~F}$. Form $13 \mathrm{~F}$ must be filed with the SEC no later than 45 days after the end of each calendar quarter. The types of securities that are reported on form $13 \mathrm{~F}$ include exchangetraded and NASDAQ-quoted stocks, equity options and warrants, convertible bonds, and shares of closed-end investment companies. All long positions in such securities with more than 10,000 shares or with a market value exceeding $\$ 200,000$ are required to be reported. Information reported on form $13 \mathrm{~F}$ includes the issuers of the securities, the security type, the Committee on Uniform Security Identification Procedures number, the number of shares, and the market value of each security owned. Managers are allowed to report aggregated holdings for different funds managed by the same management company.

\subsection{Sample Selection}

The Lipper/TASS hedge fund database provides monthly fund returns and assets under management, a snapshot of fund characteristics, and the management company/investment advisor voluntarily reported by hedge funds. The TASS hedge fund database reports data beginning in February 1977, and the most recent download covers data to February 2010. At that time there were 13,845 funds, including 5,861 live funds and 7,984 dead funds. A total of 4,024 management companies/investment advisors are listed in the TASS database and each management company can manage multiple funds.

The Thomson-Reuters Institutional (13f) Holdings dataset provides quarterly holdings by institutional investors that are obligated to file form $13 \mathrm{~F}$ with the SEC. The ThomsonReuters dataset starts from the first quarter of 1980, and the most recent downloads cover holdings until the last quarter of 2009. In order to identify investment companies that manage hedge funds, I first compile a list of hedge fund company names using the Company file in the TASS Hedge Fund datasets downloaded in February 2009. This yields a total of 4,024 investment companies that manage hedge funds. I then hand matched these hedge fund 
company names with company names in the Thomson-Reuters Institutional (13f) Holdings

dataset. There are a total of 414 investment companies matched.

\subsection{Dates on Which Funds Start or Stop Filing Form 13F}

The first quarter that a company has fling records in the Thomson (13f) dataset is identified as the quarter that an investment company starts to file form 13F. Similarly, the last quarter that a company has filing records in Thomson (13f) is identified as the quarter that an investment company stops filing form $13 \mathrm{~F}$.

Table 1 lists the number of investment companies that began filing form 13F (and were added to the database of $13 \mathrm{~F}$ filing companies) each year from 1980 to 2009 in column 1 and the number of investment companies that stopped filing form 13F (and were dropped from the $13 \mathrm{~F}$ list) in column 2 . As shown in column 1 , the number of investment companies added to the $13 \mathrm{~F}$ list increased over the first half of the sample period and peaked in year 1999. It stayed roughly stable in the second half of the sample period and dropped in year 2008. Table 2 reports the distribution of the length of $13 \mathrm{~F}$ filing periods. The majority of the investment companies have a filing period of between 2 years and 10 years. There are three investment companies that have a filing period of over 20 years.

\section{Empirical Results}

\subsection{The Impact of 13F Disclosure on Hedge Fund Performance}

\subsubsection{Hedge Fund Performance Before and During 13F Portfolio Disclosure}

In this section, I use univariate tests to investigate whether portfolio disclosure harms hedge fund performance. Only those fund families that have return data in TASS before and during $13 \mathrm{~F}$ portfolio disclosure are included in the analysis. The statistical significance of the difference in performance between disclosure and non-disclosure periods is obtained using a 
paired t-test. As shown in Table 3, hedge fund performance is worse in disclosure periods than in non-disclosure periods. The results are robust to five performance measures including raw returns, market model alpha, Fama-French three-factor alpha, Carhart four-factor alpha, and Fung-Hsieh seven-factor alpha. The differences in performance are both statistically and economically significant. For example, the Fung-Hsieh seven-factor model alpha is 0.399 percent lower per month (4.788 percent annually) during the $13 \mathrm{~F}$ disclosure period.

\subsubsection{Risk-Adjusted Performance of Calendar Time Portfolio}

I investigate whether a calendar time portfolio which long disclosed funds and short non-disclosed funds earns abnormal risk-adjusted returns. In each month t, a fund family is classified as "disclosed" if it files $13 \mathrm{~F}$ in month $\mathrm{t}-1$, otherwise it is classified as "nondisclosed." Only the fund families that file $13 \mathrm{~F}$ at least once during the sample period are included in the analysis. Table 4 reports raw returns and risk adjusted performance including market model alpha, Fama-French three-factor alpha, Carhart four-factor alpha, and FungHsieh seven-factor alpha of the calendar time portfolio. As shown in the table, raw returns and alphas obtained from the four risk models are all negative and statistically significant. For example, the alpha based on Fung-Hsieh seven-factor model is -0.283 percent monthly (3.396 percent annually). These results suggest that disclosed funds underperformance nondisclosed funds by about 3.4 percent annually.

\subsubsection{Regression Discontinuity (RD) Design}

The discontinuous change in the disclosure regime that takes effect when investment companies' assets cross the $\$ 100$ million threshold allows me to identify an effect of portfolio disclosure on hedge fund performance that is purged of potential endogeneity problems. I employ a regression discontinuity design in which the identifying assumption is that the function that relates fund size to performance does not have precisely the same jumps as the 
function that relates fund size to disclosure. This procedure is valid even if unobserved factors such as fund manager skill that affect performance are functionally related to fund size. I narrow the sample to a small neighborhood around the $\$ 100$ million threshold and use model below to detect whether there is a jump in performance when the disclosure requirement changes. Specifically, I keep the fund-year observations that have a lagged fund size greater than $\$ 70$ million and less than $\$ 130$ million. The results are robust to various width of the neighborhood such as $\$ 90$ million to $\$ 110$ million and $\$ 80$ million to $\$ 120$ million.

$$
\text { Performance }_{i, t}=\alpha+\beta \cdot \text { Disclosure }_{i, t}+\gamma_{1} \text { Size }_{i, t-1}+\gamma_{2} \text { Size }_{i, t-1}^{2}+\varepsilon_{i, t}
$$

where Performance $_{i ; t}$ is a performance measure for fund family $i$ in year $t$, Performance $_{i ; t}$ is equal to 0 if year $t$ is before investment company $i$ begins filing form $13 \mathrm{~F}$, and is equal to 1 if year $t$ is during the period that investment company files form 13F. The coefficient on Disclosure $_{i ; t}$ captures whether there is a jump in performance when the disclosure code changes from 0 to 1 . Both linear and quadratic terms of lagged assets under management are included in the model to control for the effect of fund size on fund performance. Using samples only in the small neighborhood of $\$ 100$ million also allows the results to be less dependent on the model specifications, such as the quadratic relation between size and performance.

As shown in columns (1), (3), (5), (7), and (9) in Panel A of Table 5, the coefficient on Disclosure $_{i, t}$ is negative and statistically significant across all three performance measures. There is a drop in performance that occurs in the form of a discontinuous jump that cannot be explained by continuous changes in assets under management when the regulatory regime switches from non-disclosure to disclosure.

There are also funds in TASS that have crossed the threshold of $\$ 100$ million but 
were not required to file $13 \mathrm{~F}$ because some or all of their assets are not $13(\mathrm{f})$ securities, are short positions, contain fewer than 10,000 shares, or have a market value of less than $\$ 200,000$. These non-13F filing funds provide the opportunity for a control test. If the drop in performance is due to $13 \mathrm{~F}$ disclosure, we should not observe a discontinuous drop in performance for this control group when they cross the $\$ 100$ million threshold. As shown in columns (2), (4), (6), (8), and (10) in Panel A of Table 5, the coefficient on variable Disclosure $_{i ; t}$ is not significantly different from zero, which suggests that there is no drop in performance for funds that crossed the $\$ 100$ million threshold but did not file 13F disclosure.

I also investigate whether there is a discontinuous drop when funds cross other thresholds (e.g., $\$ 70$ million or $\$ 130$ million). If the drop in performance when funds crossed the $\$ 100$ million threshold is due to $13 \mathrm{~F}$ disclosure, we should not observe drops in performance when funds cross other thresholds. As shown in Panel B of Table 5, the coefficient on Dummy $y_{i ; t}$ is not statistically different from zero when using the threshold of $\$ 70$ million or $\$ 130$ million. These results confirm that the drop in performance following disclosure is not due to a change in size or mean reversion in returns.

To address the concern that the yearly performance measure alphas estimated with twelve monthly return observations may not be very reliable due to the limitation of the sample size, I scaled each alpha estimate by its standard error and then run tests identical to those reported in Panels A and B and the results are reported in Panels C and D. By scaling the alpha estimate by its standard error, I give greater weight to the alpha estimates which are relative more precise. As shown in Panel C and Panel D, the results are qualitatively similar.

\subsection{4 'Discontinuous' Change in Performance When Funds Start to File 13}

The univariate tests in Table 3 show that fund performance is poorer in the disclosure periods than in the non-disclosure periods. If the decreased performance is due to portfolio 
disclosure, the change in fund performance should not occur slowly over time, but in the form of a sudden drop immediately after funds start to file $13 \mathrm{~F}$ disclosure. In this section, I use the following regression to test whether the change in performance occurs as soon as funds begin filing 13F:

Change in Performance $_{i, t}=\alpha+\beta_{1} \cdot 1^{\text {st }}$ Year $_{i, t}+\beta_{2} \cdot 2^{\text {nd }}$ Year $_{i, t}+\beta_{3} \cdot 3^{\text {rd }}$ Year $_{i, t}+$ $\beta_{4} \cdot 4^{\text {th }}$ Year $_{i, t}+\beta_{5} \cdot 5^{\text {th }}{ }_{i, t}+\gamma_{1} \cdot$ Change in Size ${ }_{i, t}+\gamma_{2} \cdot$ Change in Size $e_{t-1}^{2}$

Change in Performance $_{i ; t}$ is the change in performance of fund family $i$ in year $t$ from year $t-1$. The variable $1^{s t}$ Year $_{i, t}$ is equal to 1 if it is the first year in which the fund family $i$ starts to file $13 \mathrm{~F}$. I also include dummy variables for $2^{\text {nd }}, 3^{\text {rd }}$, and $4^{\text {th }}$ year and for $5^{\text {th }}$ year or later. The control variables include lagged change in linear and quadratic term of assets under management. All TASS funds except funds that report in a currency other than U.S. dollars are included in the analysis, and back-filled data are removed. Fund family and year fixed effects are included in the model and errors are clustered.

As shown in Panel A Table 6, the coefficients on variable $1^{\text {st }}$ Year $_{i ; t}$ are negative and statistically significant across all five performance measures. For example, the coefficient on variable $1^{\text {st }}$ Year $_{i, t}$ in model (1) is -0.00523 , which suggests that the drop in raw returns in the first year after funds start to file $13 \mathrm{~F}$ is 0.52 percent monthly (or 6.3 percent annually). However, the coefficients on $2^{\text {nd }}, 3^{\text {rd }}, 4^{\text {th }}$, and $5^{\text {th }}$ year dummies are not negatively statistically significant. The results suggest that the decrease in performance occurs in the first year after funds start to file 13F, which supports the argument that the drop in performance is due to $13 \mathrm{~F}$ disclosure. The coefficient on lagged change in assets under management is negative and statistically significant, which suggests diminishing returns to scale. The coefficient on lagged change in squared size is positive, which suggests that the relation between performance and size is concave. This discontinuous change in performance 
along the time dimension again lends strong support for the argument that portfolio

disclosure harms fund performance. Panel B reports the results where the alpha estimates are scaled by its standard error before being used in the test. As discussed in the previous session, this treatment is to address the concern that the sample size for estimating alpha in each year is limited (12 monthly observations). The results remain unchanged after applying this treatment.

\subsubsection{Illiquidity and the Impact of Portfolio Disclosure on Performance}

The findings in the previous sections suggest that $13 \mathrm{~F}$ portfolio disclosure leads to lower hedge fund performance. In this section, I examine the hypothesis that the cost of portfolio disclosure should be greater for funds that hold illiquid assets. In general, trades in illiquid securities result in larger price impacts than trades in liquid securities. In order to reduce the transaction cost caused by price impact, fund managers tend to employ sequential trading strategies to accumulate or dispose of an illiquid position. However, the longer it takes to accumulate or dispose of a position, the higher the likelihood and the greater the cost of being taken advantage of by frontrunners and free riders. Consistent with these arguments, I find that the drop in performance is more dramatic for funds with illiquid holdings. I use the following regression model to test whether the cost of disclosure is greater for funds with illiquid holdings:

$$
\begin{aligned}
& \text { Performance }_{i, t}=\alpha+\beta \cdot \text { Disclosure }_{i, t}+\gamma_{1} \cdot \text { Illiquidity }_{i} \cdot \text { Disclosure }_{i, t}+\gamma_{2} \cdot \text { Illiquidity }^{2} \\
& +\beta_{1} \cdot \log \text { Size }_{i, t-1}+\beta_{2} \cdot\left(\log \text { Size }_{i, t-1}^{2}\right.
\end{aligned}
$$

Illiquidity $_{i}$ is the average Amihud (2002) illiquidity measure calculated using the holdings disclosed in form 13F for fund family $i$ over all disclosing quarters. The Amihud (2002) illiquidity measure is the average daily illiquidity during the quarter preceding the $13 \mathrm{~F}$ filing quarter (where daily illiquidity is calculated as the absolute return divided by the dollar 
trading volume on that day):

Illiq $_{Q}=\frac{1}{N} \sum_{T-1}^{N} \frac{\mid \text { ret }_{t} \mid}{\text { vol }_{t} \cdot \operatorname{prc}_{t}}$

where $I_{l l i q}$ is quarterly illiquidity, $\mathrm{N}$ is the number of days in the quarter, and $\mathrm{ret}_{\mathrm{t}}$, $\mathrm{vol}_{\mathrm{t}}$, and $\operatorname{prc}_{\mathrm{t}}$ are the return, trading volume, and the price on day $t$, respectively.

As shown in Table 7, the coefficients on the interaction term between Illiquidity $_{i}$ and Disclosure $_{i ; t}$ are negative across all five models and are statistically significant except in models (1). These results suggest that portfolio disclosure is more costly for funds that have more illiquid holdings.

\subsubsection{The Impact of 13F Disclosure on Correlations of Hedge Fund Returns}

If portfolio disclosure reveals trade secrets and facilitates free-riding activities, we should expect to observe an increase in correlations between the returns of fund $i$ and the returns of other hedge funds after fund $i$ starts to file $13 \mathrm{~F}$ disclosure. To measure the correlations between the returns of fund $i$ and other hedge funds that are in the same investment style in year $t$, I regress the monthly returns of fund $i$ on the value-weighted returns in year $t$ of all hedge funds that are in the same investment style. The R-squared obtained from this regression describes how much of the return variation for fund $i$ can be explained by the index returns for all hedge funds that are in the same investment style and is used as a measure of correlations between the fund $i$ and other hedge funds that are in the same investment style.

The regression model in column (1) and (2) of Table 8 is:

$R_{i, t}^{2}=\alpha+\beta_{1} \cdot$ Disclosure $_{i, t}+\varepsilon_{i, t}$ 


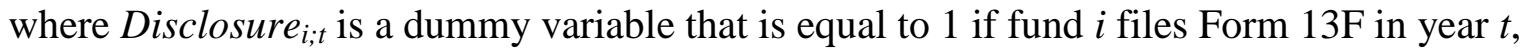
otherwise 0. Advisor fixed effects are included in the models. The models in column (3) and (4) add control variables including lagged size and lagged quadratic terms of size.

As shown in Table 8, the coefficient on variable Disclosure $_{i ; t}$ is positive and statistically significant, which indicates that there is an increase in return correlations between fund $i$ and other hedge funds that are in the same investment style after fund $i$ starts to file the $13 \mathrm{~F}$ disclosure. The increase in $\mathrm{R}_{2}$ is about 3 percent, which is also economically significant. These results provide strong evidence that there is an increase in return correlations between disclosing funds and other hedge funds when funds start to file $13 \mathrm{~F}$. These findings support the argument that portfolio disclosure reveals trade secrets and facilitates free-riding activities.

\subsection{The Impact of 13F Disclosure on Compensation Schemes}

Since portfolio disclosure allows more monitoring of fund activity, it introduces another mechanism to control the agency problem. Though agency theories have rich implications for how monitoring may interact with the fund manager's compensation incentives, the impact of disclosure on optimal compensation is still a rarely explored empirical question in the literature. The typical compensation in the hedge fund industry includes a management fee that is a fixed percentage of assets and an incentive fee that is a percentage of the profit when a fund return is positive or exceeds a "high-water mark." This incentive fee aligns the interest of managers with that of investors. However, such option-like fee structures also provide managers with an incentive to take investment risks that exceed investors' desired risk level. Investors with information about a portfolio's holdings are better able to assess the risk they are exposed to, a circumstance that disciplines risk taking by fund 
managers. Portfolio disclosure thereby reduces the cost of option-like incentive fees and allows for higher incentive fees in the optimal compensation structure.

Though TASS only provides a snapshot of the fee structure of each reporting fund, the inception date of each fund tells whether the fee structure was set before or during the period that the fund family filed $13 \mathrm{~F}$ disclosure. Because fund fees are set at the time of the inception of the fund, I compare the fees of the funds launched during the period that their fund families file $13 \mathrm{~F}$ with the fees of the funds launched before $13 \mathrm{~F}$ disclosure. In the previous section, the analysis of the impact of portfolio disclosure on hedge fund performance is conducted at the fund family level. In this section, the analysis is conducted at the fund level.

\subsubsection{Summary Statistics on Hedge Fund Compensation Schemes}

Table 9 provides summary statistics on hedge fund compensation schemes, including incentive fees, management fees, and whether funds use a high-water mark. Funds of funds are excluded from the sample because their fee structures are different. Funds that launched after their fund family stopped filing form $13 \mathrm{~F}$ are also excluded. Panel A reports and compares compensation schemes for non-13F filers and 13F filers. Similar to the definition earlier, non-13F filers refers to funds that never filed $13 \mathrm{~F}$ during the sample period and $13 \mathrm{~F}$ filers refers to funds that belong to a fund family that filed a $13 \mathrm{~F}$ at least once. As shown in Panel A of Table 8, the average incentive fee for $13 \mathrm{~F}$ filers is 18.92 percent and for non-13F filers is 18.16 percent. Thus, the incentive fees for $13 \mathrm{~F}$ filers are 0.76 percent greater than for non-13F filers, and the difference is statistically significant. The average management fee for both $13 \mathrm{~F}$ filers and non-13F filers is 1.50 percent. The percentage of funds that use a highwater mark for $13 \mathrm{~F}$ filers is 67 percent and for non-13F filers is 84 percent. The difference is 17 percent and is statistically significant. Panel B reports and compares the compensation 
scheme for funds that launched before their fund families started to file $13 \mathrm{~F}$ and for funds that launched during the period that their fund families filed 13F. The univariate test shows that funds that launched during the $13 \mathrm{~F}$ filing have higher incentive fees $(0.56$ percent, but not statistically significant) and use a high-water mark more frequently. However, such univariate tests cannot control for other factors, such as time trends, that might have affected the compensation scheme. I show the results of multivariate tests in the next section.

\subsubsection{The Impact of 13F Disclosure on Compensation Schemes}

I use the following multivariate regression to capture the effect of disclosure on incentive fees:

Incentive Fee $_{i}=\alpha+\beta \cdot$ Disclosure $_{i}+\gamma_{1} \cdot$ FamilyAssets $+\gamma_{2} \cdot$ FamilyAge $+\varepsilon_{i}$

where the dependent variable is incentive fees as a percentage term. The variable Disclosure $_{i}$ is equal to 1 if the fee structure is set during the period that a fund family files $13 \mathrm{~F}$, and is equal to 0 if the fee structure is set in the period before the fund family starts to file $13 \mathrm{~F}$. The control variables include the fund family's assets under management and family age (in log form) at the fund's inception date, and a dummy variable that indicates whether the fund family has ever filed a $13 \mathrm{~F}$ report. Year, fund category, and fund family fixed effects are included in the models and errors are clustered.

As shown in columns (1) to (5) of Table 10, the coefficients on Disclosure $_{i}$ are positive and statistically significant. The incentive fees are on average about 1 percent higher when a fund family files $13 \mathrm{~F}$ portfolio disclosure. In unreported tables, I find that there is no change in the management fee or the use of a high-water mark after funds file the $13 \mathrm{~F}$ disclosure. Overall, these results support the hypothesis that portfolio monitoring reduces risk-taking by fund managers and allows for higher convexity in the optimal compensation structure. 


\subsection{The Impact of 13F Disclosure on Fund Flows}

Whether hedge fund investors value $13 \mathrm{~F}$ portfolio disclosure is still an open question. While investors may prefer more disclosure for the increased transparency it affords, they may prefer less disclosure if disclosure hampers the performance of the funds. In addition, it is possible for hedge fund investors to negotiate directly with fund managers to obtain portfolio information privately. The value that investors attach to the $13 \mathrm{~F}$ disclosure can be measured by the fund flows in and out of the funds, after controlling for other factors that affect flows (e.g., past performance).

Flows for fund family $i$ in year $t$ are calculated as the changes in assets under management from year end $t-1$ to year end $t$ after removing the changes in assets caused by returns in year $\mathrm{t}$ and then divided by assets under management at year end $t-1$ :

$$
\text { Flow }_{i, t}=\frac{\text { Assets Under Management }}{i, t}-\text { Assets Under Management } t_{i, t-1} \cdot{\text { Re } \text { turns }_{i, t}}_{\text {Assets Under Management }}
$$

Variable Flow $_{i, t}$ is winsorized at upper 90 percent to remove the effect of extreme outliers. As shown in Panel A of Table 11, the average flow for non-13F filers is 5.6 percent per year and for $13 \mathrm{~F}$ filers is 13.2 percent per year. The difference is 7.7 percent, which is statistically significant. The average flow for $13 \mathrm{~F}$ filers before $13 \mathrm{~F}$ filing is 36.1 percent per year and is 2.8 percent per year during the period of $13 \mathrm{~F}$ filings. The difference is 33.2 percent, which is statistically significant. Therefore, the univariate analysis suggests that fund flows are lower in the disclosure period than in the non-disclosure period.

Since there are factors other than disclosure that can also affect fund flows, I use the following multivariate regression models to examine how fund flows respond to $13 \mathrm{~F}$ disclosure:

Flow $_{i, t}=\alpha+\beta \cdot$ Disclosure $_{i, t}+\gamma \cdot$ Controls $_{i, t-1}$ 
The control variables include lagged performance, lagged volatility of fund returns, lagged assets under management in log form, a lockup dummy indicating whether the fund utilizes the lockup provision, and the 13F Filing Funds Dummy variable indicating whether the fund family ever filed $13 \mathrm{~F}$ in the sample period. As shown in Panel B Table 11, the coefficient on Disclosure $_{i}$ is negative and statistically significant across all models, which indicates that flows are lower during the disclosure period. For example, model (1) suggests that the flows in the disclosure period are 14 percent lower per year than in the nondisclosure period. The coefficient on lagged performance is positive, which is consistent with the idea that flow chases past performance (Berk and Green, 2004). The coefficient on past fund volatility is negative, which suggests that hedge fund investors dislike return volatility. Overall, the results indicate that flows are lower in the periods of disclosure than in nondisclosure periods, suggesting that hedge fund investors place a negative value on $13 \mathrm{~F}$ portfolio disclosure.

\section{Conclusions}

This study contributes to the policy debate over the optimal portfolio disclosure policy by providing direct evidence that portfolio disclosure leads to a decline in hedge fund performance. The cost of portfolio disclosure to hedge fund performance is economically large ( 4 percent annually), suggesting that there is a need to improve the current form of mandatory portfolio disclosure. For example, requiring less frequent disclosures or longer delay periods might deter free-riding activities and reduce the costs of portfolio disclosure. Another alternative would be to make hedge fund disclosure reports available only to each fund's investors and to regulatory agencies. In addition, although part of the purpose of mandatory portfolio disclosure is to protect hedge fund investors, it is noteworthy that 
investment flows drop following disclosure, suggesting that hedge fund investors find disclosure undesirable. 
Table 1. The Number of Companies Added or Dropped from the List of 13F Filing Companies

This table reports the number of investment companies that began filing form $13 \mathrm{~F}$ (added to the list of 13F Filing companies) each year from 1980 to 2009 in column 1 and the number of investment companies that ceased filing form $13 \mathrm{~F}$ (and were dropped from the list of $13 \mathrm{~F}$ companies) in column 2 . The first quarter that a company has filing records in the Thomson (13f) dataset is identified as the quarter that an investment company starts to file form $13 \mathrm{~F}$, excluding the beginning of the Thomson (13f) dataset, which is the first quarter of year 1980. Similarly, the last quarter that a company has filing records in Thomson (13f) is identified as the quarter that an investment company stops filing form $13 \mathrm{~F}$, excluding the last date of the Thomson (13f) data download, which is the last quarter of year 2009.

\begin{tabular}{|c|c|c|}
\hline Year & $\begin{array}{c}\text { \# of Companies That } \\
\text { Begin Filing 13F }\end{array}$ & $\begin{array}{c}\text { \# of Companies That } \\
\text { Cease Filing 13F }\end{array}$ \\
\hline 1980 & 1 & 0 \\
\hline 1981 & 1 & 0 \\
\hline 1982 & 1 & 0 \\
\hline 1983 & 1 & 0 \\
\hline 1984 & 0 & 0 \\
\hline 1985 & 1 & 0 \\
\hline 1986 & 0 & 0 \\
\hline 1987 & 2 & 0 \\
\hline 1991 & 3 & 0 \\
\hline 1992 & 1 & 0 \\
\hline 1993 & 3 & 0 \\
\hline 1994 & 3 & 1 \\
\hline 1995 & 5 & 2 \\
\hline 1996 & 2 & 0 \\
\hline 1997 & 12 & 1 \\
\hline 1998 & 17 & 30 \\
\hline 1999 & 58 & 6 \\
\hline 2000 & 35 & 17 \\
\hline 2001 & 12 & 11 \\
\hline 2002 & 28 & 10 \\
\hline 2003 & 41 & 11 \\
\hline 2004 & 28 & 14 \\
\hline 2005 & 44 & 18 \\
\hline 2006 & 43 & 26 \\
\hline 2007 & 43 & 31 \\
\hline 2008 & 29 & 50 \\
\hline 2009 & 0 & 18 \\
\hline Total & 414 & 246 \\
\hline
\end{tabular}


Table 2. The Length of 13F Filing Periods

This table reports the distribution of the length of the $13 \mathrm{~F}$ filing periods.

\begin{tabular}{lc}
\hline Length of 13F Filing Period & \# of Investment Companies \\
\hline 1 quarter & 24 \\
2 quarters to 1 year & 52 \\
2 to 5 years & 207 \\
6 to 10 years & 101 \\
10 to 15 years & 26 \\
15 to 20 years & 1 \\
$>=20$ years & 3 \\
\hline Total & 414 \\
\hline
\end{tabular}


Table 3. Hedge Fund Performance Before and During 13F Portfolio Disclosure

This table reports the results of univariate tests on hedge fund performance before and during $13 \mathrm{~F}$ portfolio disclosure. The statistical significance on the difference in performance is obtained using paired t-tests.

\begin{tabular}{|c|c|c|c|c|c|c|c|c|}
\hline \multirow[b]{3}{*}{ Raw Returns (\%) } & \multicolumn{3}{|c|}{ Before 13F Filing } & \multicolumn{3}{|c|}{ During 13F Filing } & \multirow{2}{*}{\multicolumn{2}{|c|}{$\begin{array}{l}\text { Difference } \\
\text { Paired-t test }\end{array}$}} \\
\hline & \multirow{2}{*}{$\frac{\mathrm{n}}{152}$} & \multirow{2}{*}{$\frac{\text { mean }}{1.098 * * * *}$} & \multirow{2}{*}{$\begin{array}{c}\mathrm{sd} \\
0.779\end{array}$} & \multirow{2}{*}{$\frac{\mathrm{n}}{152}$} & \multirow{2}{*}{$\begin{array}{c}\text { mean } \\
0.529 * * * *\end{array}$} & \multirow{2}{*}{$\begin{array}{c}\text { sd } \\
0.886\end{array}$} & & \\
\hline & & & & & & & -0.569 & $* * * *$ \\
\hline \multicolumn{9}{|l|}{ Market Model } \\
\hline Alpha (\%) & 152 & $0.654 * * * *$ & 0.730 & 152 & $0.261 * * * *$ & 0.777 & -0.393 & $* * * *$ \\
\hline Beta-Market & 152 & $0.299 * * * *$ & 0.430 & 152 & $0.393 * * * *$ & 0.450 & 0.093 & $* * *$ \\
\hline Adj R-squared & 152 & 0.202 & 0.226 & 152 & 0.272 & 0.250 & 0.070 & $* * *$ \\
\hline \multicolumn{9}{|l|}{ Fama-French 3 Factor Model } \\
\hline Alpha (\%) & 152 & $0.594 * * * *$ & 0.697 & 152 & $0.215^{* * *}$ & 0.838 & -0.379 & $* * * *$ \\
\hline Beta-Market & 152 & $0.285 * * * *$ & 0.426 & 152 & $0.388 * * * *$ & 0.421 & 0.103 & $* * *$ \\
\hline Beta-SMB & 152 & $0.206 * * * *$ & 0.272 & 152 & $0.115 * * * *$ & 0.325 & -0.091 & $* * *$ \\
\hline Beta-HML & 152 & $0.137 * * * *$ & 0.358 & 152 & -0.020 & 0.446 & -0.158 & $* * * *$ \\
\hline R-squared (Adj) & 152 & 0.276 & 0.248 & 152 & 0.340 & 0.266 & 0.063 & $* * *$ \\
\hline \multicolumn{9}{|l|}{ Fama-French 4 Factor Model } \\
\hline Alpha (\%) & 152 & 0.561 & 0.709 & 152 & $0.175^{* * *}$ & 0.812 & -0.386 & $* * * *$ \\
\hline Beta-Market & 152 & $0.283 * * * *$ & 0.414 & 152 & $0.389 * * * *$ & 0.430 & 0.106 & $* * *$ \\
\hline Beta-SMB & 152 & $0.193 * * * *$ & 0.312 & 152 & $0.125 * * * *$ & 0.327 & -0.068 & $* *$ \\
\hline Beta-HML & 152 & $0.155^{* * * * *}$ & 0.366 & 152 & 0.002 & 0.427 & -0.154 & $* * * *$ \\
\hline Beta-Momentum & 152 & 0.030 & 0.272 & 152 & 0.026 & 0.256 & -0.004 & \\
\hline R-squared (Adj) & 152 & 0.306 & 0.251 & 152 & 0.370 & 0.262 & 0.064 & $* * *$ \\
\hline \multicolumn{9}{|l|}{ Fung and Hsieh 7 Factor Model } \\
\hline Alpha (\%) & 152 & 0.720 & 0.792 & 152 & 0.321 & 0.910 & -0.399 & $* * * *$ \\
\hline Beta-Bond Trend-Following & 152 & -0.004 & 0.061 & 152 & $-0.010^{*}$ & 0.069 & -0.006 & \\
\hline Beta-Currency Trend-Following & 152 & 0.006 & 0.050 & 152 & $0.007 * *$ & 0.043 & 0.002 & \\
\hline Beta-Commodity Trend-Following & 152 & 0.004 & 0.054 & 152 & $0.011^{* *}$ & 0.060 & 0.008 & \\
\hline Beta-S\&P 500 & 152 & $0.249 * * * *$ & 0.433 & 152 & $0.291 * * * *$ & 0.461 & 0.042 & \\
\hline Beta-SC-LC & 152 & $0.184 * * * *$ & 0.319 & 152 & $0.049 * * *$ & 0.185 & -0.135 & \\
\hline Beta-10-year Treasury Yield & 152 & -0.648 & 4.893 & 152 & -0.086 & 3.869 & 1.481 & \\
\hline Beta-Credit Spread & 152 & $-1.567 * *$ & 8.350 & 152 & $-3.043 * * * *$ & 6.806 & -2.395 & \\
\hline R-squared (Adj) & 152 & 0.244 & 0.278 & 152 & 0.333 & 0.288 & 0.089 & $* * *$ \\
\hline
\end{tabular}




\section{Table 4. Calendar Time Portfolios}

This table reports raw and risk-adjusted returns for a calendar time portfolio that longs disclosed funds and shorts non-disclosed funds. In month $t$, a fund family is classified as "disclosed" if it files $13 \mathrm{~F}$ in month $t$ - 1 , otherwise it is classified as "non-disclosed."

\begin{tabular}{|c|c|c|c|c|c|}
\hline & $\begin{array}{c}(1) \\
\text { Raw } \\
\text { Return }\end{array}$ & $\begin{array}{c}(2) \\
\text { Market } \\
\text { Model }\end{array}$ & $\begin{array}{c}\text { (3) } \\
\text { FF-3Factor } \\
\text { Model }\end{array}$ & $\begin{array}{c}(4) \\
\text { Carhart } 4 \\
\text { Factor Model } \\
\end{array}$ & $\begin{array}{c}\text { (5) } \\
\text { Fung-Hsieh } 7 \\
\text { Factor Model } \\
\end{array}$ \\
\hline Constant & $\begin{array}{c}- \\
0.00313 \\
* * \\
(-2.34)\end{array}$ & $\begin{array}{c}- \\
0.00330 * \\
* * \\
(-2.74) \\
0.147 * * *\end{array}$ & $\begin{array}{c}-0.00226^{* *} \\
(-2.24)\end{array}$ & $\begin{array}{c}-0.00231^{* *} \\
(-2.23)\end{array}$ & $\begin{array}{c}-0.00283^{* *} \\
(-2.12)\end{array}$ \\
\hline Market & & $\begin{array}{c}* \\
(3.68)\end{array}$ & $\begin{array}{l}0.0767 * * * \\
\quad(2.71)\end{array}$ & $\begin{array}{l}0.0799 * * \\
(2.27)\end{array}$ & \\
\hline SMB & & & $\begin{array}{c}-0.00912 \\
(-0.29)\end{array}$ & $\begin{array}{r}-0.0117 \\
(-0.35)\end{array}$ & \\
\hline HML & & & $\begin{array}{c}-0.159^{* * * * *} \\
\quad(-4.66)\end{array}$ & $\begin{array}{c}-0.158^{* * * * *} \\
(-4.56)\end{array}$ & \\
\hline Momentum & & & & $\begin{array}{c}0.00624 \\
(0.31)\end{array}$ & \\
\hline $\begin{array}{l}\text { Bond Trend- } \\
\text { Following }\end{array}$ & & & & & $\begin{array}{c}0.00335 \\
(0.48)\end{array}$ \\
\hline $\begin{array}{l}\text { Currency Trend- } \\
\text { Following }\end{array}$ & & & & & $\begin{array}{c}0.00220 \\
(0.51)\end{array}$ \\
\hline $\begin{array}{l}\text { Commodity Trend- } \\
\text { Following }\end{array}$ & & & & & $\begin{array}{c}0.00324 \\
(0.49)\end{array}$ \\
\hline S\&P 500 & & & & & $\begin{array}{c}0.122 * * * \\
(3.24)\end{array}$ \\
\hline SC_LC & & & & & $\begin{array}{c}-0.000885 \\
(-0.52)\end{array}$ \\
\hline Credit Spread & & & & & $\begin{array}{l}-0.741 \\
(-0.52)\end{array}$ \\
\hline $\begin{array}{l}\text { 10-year Treasury } \\
\text { Yield }\end{array}$ & & & & & $\begin{array}{c}-0.0211 \\
(-0.04)\end{array}$ \\
\hline $\begin{array}{l}\text { Observations } \\
\text { Adjusted R-squared }\end{array}$ & 108 & $\begin{array}{c}108 \\
0.284\end{array}$ & $\begin{array}{c}108 \\
0.475\end{array}$ & $\begin{array}{c}108 \\
0.471\end{array}$ & $\begin{array}{c}108 \\
0.173 \\
\end{array}$ \\
\hline
\end{tabular}


Table 5. Regression Discontinuity Design

This table reports the results of regression discontinuity (RD) design with samples narrowed to a small neighborhood around the threshold of $\$ 100$ million ( $\delta$ is chosen to represent $\$ 30$ million). In Panel $\mathrm{A}$, funds that filed $13 \mathrm{~F}$ during the sample period are included in the analysis in model (1), (3), (5), (7), and (9). Performance $_{i, t}$ is a performance measure for fund family $i$ in year $t$. I use five different performance measures in my analysis: raw returns, market model alpha, Fama-French three-factor model alpha, Carhart four-factor model alpha, and Fung-Hsieh seven-factor model alpha. All are calculated using monthly fund returns reported in TASS. Disclosure ${ }_{i, t}$ is equal to 0 if year $t$ is before the investment company $i$ starts to file form 13F, and is equal to 1 if year $t$ is during the period that investment company files form $13 \mathrm{~F}$.

Performance $_{i, t}=\alpha+\beta \cdot$ Disclosure $_{i, t}+\gamma_{1} \cdot$ Size $_{i, t-1}+\gamma_{2} \cdot$ Size $_{i, t-1}^{2}+\varepsilon_{i, t}$ Sample: $\$ 100$ million $-\delta<=$ Size $_{i, t-1}<=\$ 100$ million $+\delta$

Funds that never filed 13F during the sample period are used as a control group for the analysis, and results are reported in model (2), (4), (6), (8), and (10).

Dummy $_{i, t}$ is equal to 1 if the size of investment company $i$ in year $t-1$ is equal or greater than $\$ 100$ million, and is equal to 0 otherwise.

$$
\begin{aligned}
& \text { Performance }_{i, t}=\alpha+\beta \cdot \text { Dummy }_{i, t}+\gamma_{1} \cdot \text { Size }_{i, t-1}+\gamma_{2} \cdot \text { Size }_{i, t-1}^{2}+\varepsilon_{i, t} \\
& \text { Dummy }_{i, t}=\left\{\begin{array}{l}
1, \quad \text { if Size } e_{i, t-1}>=\$ 100 \text { million } \\
0, \quad \text { if Size } e_{i, t-1}<\$ 100 \text { million }
\end{array}\right.
\end{aligned}
$$

Sample: $\$ 100$ million $-\delta<=$ Size $_{i, t-1}<=\$ 100$ million $+\delta$

In Panel B, other thresholds, including \$70 million and \$130 million, are chosen for the analysis. Specifically, Dummy ${ }_{i, t}$ is equal to 1 if the size of investment company $i$ in year $t-1$ is equal or greater than $\$ 70$ (or \$130) million, and is equal to 0 otherwise.

$$
\text { Performance }_{i, t}=\alpha+\beta \cdot \text { Dummy }_{i, t}+\gamma_{1} \cdot \text { Size }_{i, t-1}+\gamma_{2} \cdot \text { Size }_{i, t-1}^{2}+\varepsilon_{i, t}
$$

Dummy $_{i, t}=\left\{\begin{array}{l}1, \quad \text { if Size } e_{i, t-1}>=\$ 70(\text { or } \$ 130) \text { million } \\ 0, \quad \text { if Size } e_{i, t-1}<\$ 70(\text { or } \$ 130) \text { million }\end{array}\right.$

Sample: $\$ 70$ (or $\$ 130$ million) $-\delta<=$ Size $_{\mathrm{i}, \mathrm{t}-1}<=\$ 70$ (or $\$ 130$ million) $+\delta$

In Panel C, the performance measure - alpha for investment company $i$ in year $t$ is scaled by the standard error of the alpha estimate. These error-scaled alphas are then used in the regression discontinuity (RD) design that is identical to the tests in Panel A. Similarly, the alphas used in Panel D are scaled by their standard errors and the tests are identical to those in Panel B. 
Panel A. Funds that Did and Did Not File 13F When Crossing the Threshold of \$100 Million

$*, * *, * * *$, and $* * * *$ denote statistical significance at $10,5,1$, and 0.1 percent level, respectively.

\begin{tabular}{|c|c|c|c|c|c|c|c|c|c|c|}
\hline & \multicolumn{2}{|c|}{ Raw Return } & \multicolumn{2}{|c|}{$\begin{array}{c}\text { Market Model } \\
\text { Alpha } \\
\end{array}$} & \multicolumn{2}{|c|}{$\begin{array}{c}\text { FF 3-Factor } \\
\text { Alpha }\end{array}$} & \multicolumn{2}{|c|}{$\begin{array}{c}\text { Carhart 4- } \\
\text { Factor Alpha }\end{array}$} & \multicolumn{2}{|c|}{$\begin{array}{l}\text { Fung-Hsieh 7- } \\
\text { Factor Alpha }\end{array}$} \\
\hline & $\begin{array}{c}\text { Test } \\
\text { Grou } \\
\text { p }\end{array}$ & $\begin{array}{c}\text { Contr } \\
\text { ol }\end{array}$ & $\begin{array}{c}\text { Test } \\
\text { Group }\end{array}$ & $\begin{array}{c}\text { Cont } \\
\text { rol } \\
\text { Grou } \\
\mathrm{p} \\
\end{array}$ & $\begin{array}{c}\text { Test } \\
\text { Group }\end{array}$ & $\begin{array}{c}\text { Contr } \\
\text { ol } \\
\text { Grou } \\
\text { p } \\
\end{array}$ & $\begin{array}{c}\text { Test } \\
\text { Group }\end{array}$ & $\begin{array}{c}\text { Contr } \\
\text { ol } \\
\text { Grou } \\
\text { p }\end{array}$ & $\begin{array}{c}\text { Test } \\
\text { Group }\end{array}$ & $\begin{array}{c}\text { Contro } \\
1 \\
\text { Group }\end{array}$ \\
\hline & (1) & (2) & (3) & (4) & (5) & (6) & (7) & (8) & (9) & $(10)$ \\
\hline $\begin{array}{l}\text { Disclos } \\
\text { ure } \\
\text { /Dumm }\end{array}$ & $\begin{array}{c}- \\
0.005 \\
71 \\
(-\end{array}$ & $\begin{array}{c}- \\
0.000 \\
951 \\
(-\end{array}$ & $\begin{array}{c}- \\
0.0055 \\
4 * *\end{array}$ & $\begin{array}{l}0.00 \\
109 \\
(0.7\end{array}$ & $\begin{array}{c}- \\
0.0059 \\
9 * *\end{array}$ & $\begin{array}{c}- \\
0.001 \\
24 \\
(-\end{array}$ & $\begin{array}{c}- \\
0.0061 \\
6^{* *}\end{array}$ & $\begin{array}{c}- \\
0.001 \\
30 \\
(-\end{array}$ & $\begin{array}{c}- \\
0.00466 \\
*\end{array}$ & $\begin{array}{c}- \\
0.0033 \\
5\end{array}$ \\
\hline $\begin{array}{c}y \\
\text { Lagged }\end{array}$ & 1.59) & $0.70)$ & $(-2.26)$ & 1) & $(-2.78)$ & $0.62)$ & $(-2.58)$ & $0.73)$ & $(-1.81)$ & $(-1.16)$ \\
\hline Size & $\begin{array}{l}9.93 \\
(0.56\end{array}$ & 9.34 & -3.31 & $\begin{array}{l}3.44 \\
(1.0\end{array}$ & -5.98 & $\begin{array}{l}0.979 \\
(0.28\end{array}$ & -6.87 & $\begin{array}{l}0.486 \\
(0.13\end{array}$ & -10.1 & 3.36 \\
\hline $\begin{array}{l}\left(10^{-10}\right) \\
\text { Lagged }\end{array}$ & ) & $(1.51)$ & $(-0.42)$ & 2) & $(-0.93)$ & $\begin{array}{l}\text { ) } \\
-\end{array}$ & $(-1.02)$ & ) & $(-1.40)$ & $(0.54)$ \\
\hline $\mathrm{Size}^{2}$ & -5.47 & -4.68 & 1.42 & $\begin{array}{c}1.85 \\
(-\end{array}$ & 2.69 & 0.129 & 3.08 & 0.159 & 4.49 & -1.2 \\
\hline$\left(10^{-18}\right)$ & $\begin{array}{c}(- \\
0.60) \\
-\end{array}$ & $\begin{array}{c}(- \\
1.47) \\
-\end{array}$ & $(0.35)$ & $\begin{array}{c}1.03 \\
-\end{array}$ & $(0.83)$ & $\begin{array}{c}(- \\
0.07) \\
-\end{array}$ & $(0.89)$ & $\begin{array}{c}(0.09 \\
) \\
-\end{array}$ & $(1.23)$ & $(-0.39)$ \\
\hline $\begin{array}{c}\text { Constan } \\
t\end{array}$ & $\begin{array}{c}0.032 \\
7\end{array}$ & $\begin{array}{c}0.038 \\
7\end{array}$ & 0.0250 & $\begin{array}{c}0.01 \\
28 \\
(-\end{array}$ & 0.0372 & $\begin{array}{c}0.004 \\
99\end{array}$ & 0.0418 & $\begin{array}{l}0.003 \\
73\end{array}$ & 0.0597 & 0.0166 \\
\hline & $\begin{array}{c}(- \\
0.39)\end{array}$ & $\stackrel{(-}{1.23)}$ & $(0.66)$ & $\begin{array}{c}0.78 \\
)\end{array}$ & $(1.21)$ & $\begin{array}{c}(- \\
0.29)\end{array}$ & $(1.30)$ & $\begin{array}{c}(- \\
0.19)\end{array}$ & (1.68) & $(-0.53)$ \\
\hline $\begin{array}{c}\text { Observa } \\
\text { tions } \\
\text { R- } \\
\text { squared }\end{array}$ & 0.038 & 0.005 & 0.041 & $\begin{array}{c}796 \\
0.00 \\
1\end{array}$ & 0.064 & 0.004 & 0.070 & 0.003 & 0.026 & 796 \\
\hline
\end{tabular}


Panel B. Other Thresholds (\$70 million and \$130 million)

$*$, **, ***, and **** denote statistical significance at $10,5,1$, and 0.1 percent level, respectively.

\begin{tabular}{|c|c|c|c|c|c|c|c|c|c|c|}
\hline & \multicolumn{2}{|c|}{ Raw Return } & \multicolumn{2}{|c|}{$\begin{array}{l}\text { Market Model } \\
\text { Alpha }\end{array}$} & \multicolumn{2}{|c|}{$\begin{array}{l}\text { FF 3-Factor } \\
\text { Alpha }\end{array}$} & \multicolumn{2}{|c|}{$\begin{array}{c}\text { Carhart 4- } \\
\text { Factor Alpha }\end{array}$} & \multicolumn{2}{|c|}{$\begin{array}{c}\text { Fung-Hsieh 7- } \\
\text { Factor Alpha } \\
\end{array}$} \\
\hline & $\$ 70 \mathrm{M}$ & $\begin{array}{c}\$ 130 \\
\mathrm{M}\end{array}$ & $\$ 70 \mathrm{M}$ & $\begin{array}{c}\$ 130 \\
\mathrm{M}\end{array}$ & $\$ 70 \mathrm{M}$ & $\begin{array}{c}\$ 130 \\
\mathrm{M}\end{array}$ & $\$ 70 \mathrm{M}$ & $\begin{array}{c}\$ 130 \\
\mathrm{M} \\
\end{array}$ & $\$ 70 \mathrm{M}$ & $\$ 130 \mathrm{M}$ \\
\hline $\begin{array}{l}\text { Disclos } \\
\text { ure } \\
\text { /Dumm }\end{array}$ & $\begin{array}{l}0.000 \\
0174\end{array}$ & $\begin{array}{l}0.00 \\
527 \\
(1.2\end{array}$ & $\begin{array}{c}0.0004 \\
01\end{array}$ & $\begin{array}{l}0.00 \\
266 \\
0.9\end{array}$ & $\begin{array}{c}0.0000 \\
0908\end{array}$ & $\begin{array}{c}- \\
0.000 \\
747 \\
(-\end{array}$ & $\begin{array}{c}0.000 \\
189\end{array}$ & $\begin{array}{c}0.001 \\
97 \\
(-\end{array}$ & $\begin{array}{c}0.0010 \\
5\end{array}$ & $\begin{array}{c}0.0017 \\
4\end{array}$ \\
\hline $\begin{array}{c}y \\
\text { Lagged }\end{array}$ & $(0.01)$ & $\begin{array}{l}5) \\
-\end{array}$ & $(0.33)$ & 2) & $(-0.01)$ & $0.35)$ & $(0.13)$ & $0.88)$ & $(-0.43)$ & $(0.57)$ \\
\hline Size & -3.42 & $\begin{array}{c}1.07 \\
(-\end{array}$ & -1.66 & 3.52 & -1.56 & 5.64 & -1.62 & 4.23 & -0.697 & 3.46 \\
\hline$\left(10^{-10}\right)$ & $\stackrel{(-}{1.23)}$ & $\begin{array}{c}0.17 \\
) \\
-\end{array}$ & $(-1.63)$ & $\begin{array}{l}(0.6 \\
3)\end{array}$ & $(-1.30)$ & $\begin{array}{c}(1.03 \\
)\end{array}$ & $\stackrel{(-}{1.18)}$ & $(0.75)$ & $(-0.24)$ & $(0.60)$ \\
\hline $\begin{array}{l}\text { Lagged } \\
\text { Size }^{2}\end{array}$ & 2.82 & $\begin{array}{c}0.08 \\
88 \\
(-\end{array}$ & 1.24 & $\begin{array}{c}- \\
1.64 \\
(-\end{array}$ & 1.25 & -2.07 & 1.26 & -1.4 & 0.947 & -1.38 \\
\hline$\left(10^{-18}\right)$ & $(1.26)$ & $\begin{array}{c}0.04 \\
)\end{array}$ & $(1.36)$ & $\begin{array}{c}0.75 \\
) \\
-\end{array}$ & $(1.29)$ & $\begin{array}{c}(- \\
0.94) \\
-\end{array}$ & (1.09) & $\begin{array}{c}(- \\
0.62) \\
-\end{array}$ & $(0.42)$ & $(-0.60)$ \\
\hline $\begin{array}{c}\text { Constan } \\
\mathrm{t}\end{array}$ & $\begin{array}{c}0.015 \\
3^{* *}\end{array}$ & $\begin{array}{c}0.01 \\
91\end{array}$ & $\begin{array}{c}0.0078 \\
2 * * *\end{array}$ & $\begin{array}{c}0.01 \\
56 \\
(-\end{array}$ & $\begin{array}{c}0.0065 \\
4\end{array}$ & $\begin{array}{c}0.034 \\
5\end{array}$ & $\begin{array}{c}0.006 \\
03\end{array}$ & $\begin{array}{c}0.028 \\
0\end{array}$ & $\begin{array}{c}0.0032 \\
3\end{array}$ & $\begin{array}{c}- \\
0.0189\end{array}$ \\
\hline & (2.89) & $\begin{array}{c}(0.4 \\
5)\end{array}$ & $(3.10)$ & $\begin{array}{c}0.45 \\
)\end{array}$ & $(1.57)$ & $\begin{array}{l}(- \\
1.04)\end{array}$ & $(1.35)$ & $\begin{array}{c}(- \\
0.79)\end{array}$ & $(0.37)$ & $(-0.51)$ \\
\hline $\begin{array}{c}\text { Observa } \\
\text { tions } \\
\text { R- }\end{array}$ & 1500 & $\begin{array}{c}707 \\
0.00 \\
5\end{array}$ & 1500 & $\begin{array}{c}707 \\
0.00 \\
3\end{array}$ & 1500 & 707 & 1500 & 707 & 1500 & 707 \\
\hline
\end{tabular}


Panel C. Funds that Did and Did Not File 13F When Crossing the Threshold of $\$ 100$ Million (Error-Scaled)

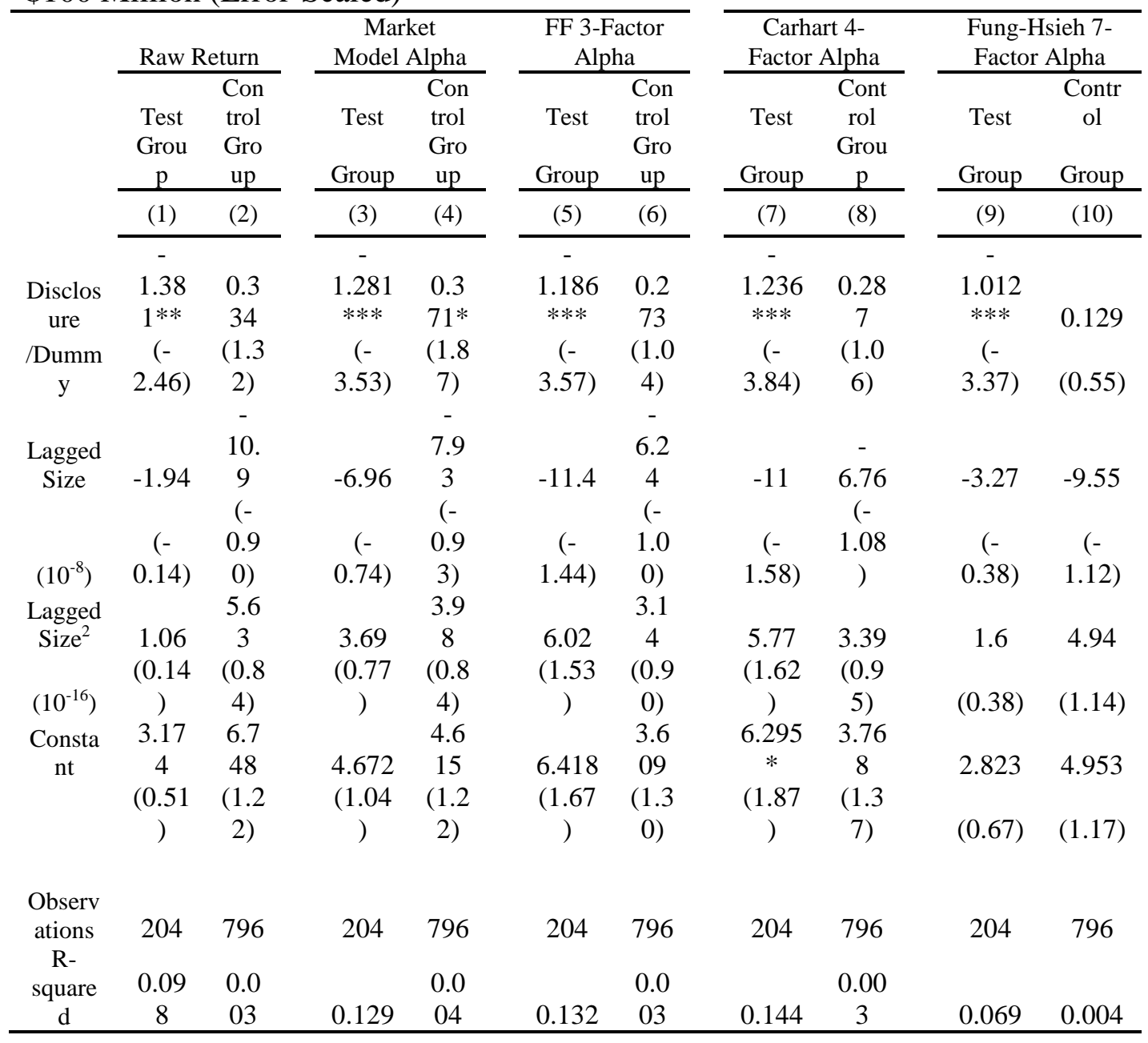

$*, * *, * * *$, and $* * * *$ denote statistical significance at $10,5,1$, and 0.1 percent

level, respectively. 
Panel D. Other Thresholds (\$70 million and \$130 million) (Error-Scaled) $*$, **, ***, and **** denote statistical significance at $10,5,1$, and 0.1 percent level, respectively.

\begin{tabular}{|c|c|c|c|c|c|c|c|c|c|c|}
\hline & \multicolumn{2}{|c|}{$\begin{array}{c}\text { Raw } \\
\text { Return }\end{array}$} & \multicolumn{2}{|c|}{$\begin{array}{l}\text { Market } \\
\text { Model Alpha }\end{array}$} & \multicolumn{2}{|c|}{$\begin{array}{l}\text { FF 3- Factor } \\
\text { Alpha }\end{array}$} & \multicolumn{2}{|c|}{$\begin{array}{c}\text { Carhart 4- } \\
\text { Factor Alpha }\end{array}$} & \multicolumn{2}{|c|}{$\begin{array}{c}\text { Fung-Hsieh 7- } \\
\text { Factor Alpha } \\
\end{array}$} \\
\hline & $\begin{array}{c}\$ 70 \\
\mathrm{M} \\
\end{array}$ & $\begin{array}{l}\$ 13 \\
0 \mathrm{M} \\
\end{array}$ & $\begin{array}{c}\$ 70 \\
\mathrm{M} \\
\end{array}$ & $\begin{array}{c}\$ 130 \\
\mathrm{M} \\
\end{array}$ & $\begin{array}{c}\$ 70 \\
\mathrm{M} \\
\end{array}$ & $\begin{array}{c}\$ 130 \\
\mathrm{M} \\
\end{array}$ & $\begin{array}{c}\$ 70 \\
\mathrm{M}\end{array}$ & $\begin{array}{c}\$ 130 \\
\mathrm{M}\end{array}$ & $\begin{array}{c}\$ 70 \\
\mathrm{M} \\
\end{array}$ & $\$ 130 \mathrm{M}$ \\
\hline $\begin{array}{l}\text { Disclos } \\
\text { ure }\end{array}$ & $\begin{array}{l}0.3 \\
90\end{array}$ & $\begin{array}{c}- \\
0.1 \\
27 \\
(-\end{array}$ & $\begin{array}{c}0.38 \\
6\end{array}$ & -0.318 & $\begin{array}{l}0.3 \\
35\end{array}$ & $0 . \overline{317}$ & $\begin{array}{c}0.29 \\
6\end{array}$ & -0.357 & 0.228 & -0.159 \\
\hline /Dumm & $(1.0$ & 0.2 & (1.7 & $(-$ & (1.6 & $(-$ & $(1.34$ & & & \\
\hline $\begin{array}{c}y \\
\text { Lagged }\end{array}$ & $\begin{array}{c}6) \\
3.9\end{array}$ & $\begin{array}{l}0) \\
9.5\end{array}$ & 2) & $0.77)$ & 1) & $0.94)$ & ) & $(-0.89)$ & $(0.73)$ & $(-0.45)$ \\
\hline $\begin{array}{l}\text { Size } \\
\left(10^{-8}\right)\end{array}$ & $\begin{array}{c}5 \\
(0.9 \\
6) \\
-\end{array}$ & $\begin{array}{c}1 \\
(0.6 \\
4) \\
-\end{array}$ & $\begin{array}{c}1.84 \\
(0.6 \\
5)\end{array}$ & $(0.58)$ & $\begin{array}{c}2.1 \\
(0.7 \\
5) \\
-\end{array}$ & $\begin{array}{c}5.37 \\
(0.60 \\
)\end{array}$ & $\begin{array}{c}1.88 \\
(0.63 \\
)\end{array}$ & $(0.45)$ & (1.18) & $(0.38)$ \\
\hline $\begin{array}{l}\text { Lagged } \\
\text { Size }^{2}\end{array}$ & $\begin{array}{c}3.1 \\
1 \\
(-\end{array}$ & $\begin{array}{l}3.1 \\
8 \\
(-\end{array}$ & $\begin{array}{c}- \\
1.75 \\
(-\end{array}$ & -1.98 & $\begin{array}{l}1.9 \\
2 \\
(-\end{array}$ & -1.78 & -1.73 & -1.21 & -2.81 & -1.01 \\
\hline$\left(10^{-16}\right)$ & $\begin{array}{l}1.0 \\
0)\end{array}$ & $\begin{array}{c}0.5 \\
8) \\
-\end{array}$ & $\begin{array}{c}0.79 \\
)\end{array}$ & $\begin{array}{c}(- \\
0.50)\end{array}$ & $\begin{array}{c}0.9 \\
0) \\
-\end{array}$ & $\begin{array}{c}(- \\
0.53)\end{array}$ & $\begin{array}{c}(- \\
0.79) \\
-\end{array}$ & $(-0.36)$ & $\begin{array}{c}(- \\
1.13)\end{array}$ & $(-0.29)$ \\
\hline $\begin{array}{c}\text { Constan } \\
\mathrm{t}\end{array}$ & $\begin{array}{l}0.0 \\
636\end{array}$ & $\begin{array}{c}4.8 \\
16 \\
(-\end{array}$ & $\begin{array}{c}0.07 \\
54\end{array}$ & -3.420 & $\begin{array}{c}0.1 \\
79 \\
(-\end{array}$ & $\begin{array}{c}- \\
3.002\end{array}$ & $\begin{array}{c}0.18 \\
0\end{array}$ & -2.335 & 0.755 & -1.820 \\
\hline & $\begin{array}{c}(0.0 \\
5)\end{array}$ & $\begin{array}{l}0.5 \\
0)\end{array}$ & $\begin{array}{c}(0.0 \\
8)\end{array}$ & $\begin{array}{c}(- \\
0.49)\end{array}$ & $\begin{array}{l}0.1 \\
9)\end{array}$ & $0.51)$ & $0.17)$ & $(-0.40)$ & $\begin{array}{c}(- \\
0.83)\end{array}$ & $(-0.33)$ \\
\hline $\begin{array}{c}\text { Observ } \\
\text { ations } \\
\text { R- } \\
\text { squared }\end{array}$ & $\begin{array}{c}150 \\
0 \\
0.0 \\
03 \\
\end{array}$ & $\begin{array}{c}707 \\
0.0 \\
01 \\
\end{array}$ & $\begin{array}{c}150 \\
0 \\
0.00 \\
3 \\
\end{array}$ & $\begin{array}{r}707 \\
0.001 \\
\end{array}$ & $\begin{array}{c}150 \\
0 \\
0.0 \\
03 \\
\end{array}$ & 0.001 & $\begin{array}{c}1500 \\
0.00 \\
2 \\
\end{array}$ & 0.001 & 1500 & 0.001 \\
\hline
\end{tabular}


Table 6. Change in Performance When Funds Start to File 13F

This table reports the results of the following regression model:

$$
\begin{aligned}
& \text { Change in Performance }{ }_{i, t}=\alpha+\beta_{1} \cdot 1^{\text {st }} \text { Year }_{i, t}+\beta_{2} \cdot 2^{\text {nd }} \text { Year }_{i, t}+\beta_{3} \cdot 3^{\text {rd }} \text { Year }_{i, t}+ \\
& \beta_{4} \cdot 4^{\text {th }} \text { Year }_{i, t}+\beta_{5} \cdot 5^{\text {th }+}{ }_{i, t}+\gamma_{1} \cdot \text { Change in Size } e_{i, t}+\gamma_{2} \cdot \text { Change in Size }_{t-1}^{2}
\end{aligned}
$$

Change in Performance Ci,t $_{\text {is }}$ the change in performance of fund family $i$ in year $t$ from year $t-1$. The variable $1^{\text {st }}$ Year $_{i, t}$ is equal to 1 if it is the first year since fund family $i$ start to file $13 \mathrm{~F}$. I also include dummy variables for $2^{\text {nd }}, 3^{\text {rd }}, 4^{\text {th }}$, and $5^{\text {th }}$ year or later. The control variables include lagged change in linear and quadratic term of assets under management. All investment companies that report to the TASS dataset are included in the analysis. Fund family and year fixed effects are included in the model and errors are clustered. The sample period is from June 1990 to February 2010 after removing the backfilled data. 
Panel A. Change in Performance When Funds Start to File 13F

\begin{tabular}{|c|c|c|c|c|c|}
\hline & \multicolumn{5}{|c|}{ Change in Alpha } \\
\hline & $\begin{array}{c}\text { Raw } \\
\text { Return }\end{array}$ & $\begin{array}{l}\text { Market } \\
\text { Model }\end{array}$ & FF3 Factor & $\begin{array}{c}\text { Carhart } 4 \\
\text { Factor } \\
\end{array}$ & $\begin{array}{c}\text { Fung-Hsieh } 7 \\
\text { Factor } \\
\end{array}$ \\
\hline & (1) & (2) & (3) & (4) & $(5)$ \\
\hline $1^{\text {st }}$ Year & $\begin{array}{c}-0.00492 * \\
(-2.02)\end{array}$ & $\begin{array}{c}-0.00432 * \\
(-1.83)\end{array}$ & $\begin{array}{c}-0.00770 * * * \\
(-3.63)\end{array}$ & $\begin{array}{c}-0.00818^{* * * *} \\
(-3.63)\end{array}$ & $\begin{array}{c}-0.00438^{*} \\
(-1.80)\end{array}$ \\
\hline $2^{\text {nd }}$ Year & $\begin{array}{c}-0.00247 \\
(-0.75)\end{array}$ & $\begin{array}{c}-0.00323 \\
(-1.17)\end{array}$ & $\begin{array}{c}-0.00215 \\
(-0.74)\end{array}$ & $\begin{array}{c}-0.00255 \\
(-0.69)\end{array}$ & $\begin{array}{c}-0.00282 \\
(-0.99)\end{array}$ \\
\hline $3^{\text {rd }}$ Year & $\begin{array}{c}-0.00243 \\
(-0.87)\end{array}$ & $\begin{array}{c}-0.00278 \\
(-0.99)\end{array}$ & $\begin{array}{c}-0.00334 \\
(-0.93)\end{array}$ & $\begin{array}{c}-0.00195 \\
(-0.38)\end{array}$ & $\begin{array}{c}-0.000343 \\
(-0.07)\end{array}$ \\
\hline $4^{\text {th }}$ Year & $\begin{array}{c}-0.00249 \\
(-0.76)\end{array}$ & $\begin{array}{c}-0.00138 \\
(-0.52)\end{array}$ & $\begin{array}{c}-0.00243 \\
(-0.63)\end{array}$ & $\begin{array}{c}-0.00142 \\
(-0.29)\end{array}$ & $\begin{array}{c}-0.000343 \\
(-0.05)\end{array}$ \\
\hline $5^{\text {th+ }}$ Year & $\begin{array}{c}-0.00209 \\
(-0.65)\end{array}$ & $\begin{array}{c}-0.00299 \\
(-0.91)\end{array}$ & $\begin{array}{c}-0.00571 \\
(-1.53)\end{array}$ & $\begin{array}{c}-0.00492 \\
(-1.19)\end{array}$ & $\begin{array}{c}-0.00508 \\
(-0.75)\end{array}$ \\
\hline $\begin{array}{l}\text { Lag Change in } \\
\text { Size }\end{array}$ & $-1.36 * * * *$ & $-0.974 * * * *$ & $-0.835 * * * *$ & $-0.805 * * * *$ & $-0.481 * * *$ \\
\hline $\begin{array}{l}\left(\mathrm{x} 10^{-11}\right) \\
\text { Lag Change in }\end{array}$ & $(-6.16)$ & $(-9.66)$ & $(-7.27)$ & $(-6.69)$ & $(-3.12)$ \\
\hline $\begin{array}{l}\operatorname{Size}^{2} \\
\left(\mathrm{x} 10^{-22}\right)\end{array}$ & $\begin{array}{c}7.20 * * * * \\
(6.80)\end{array}$ & $\begin{array}{c}5.64 * * * * \\
(8.89)\end{array}$ & $\begin{array}{c}4.89 * * * * \\
(5.86)\end{array}$ & $\begin{array}{c}4.50 * * * * \\
(5.55)\end{array}$ & $\begin{array}{c}3.55 * * * \\
(4.05)\end{array}$ \\
\hline Constant & $\begin{array}{l}0.0217 \\
(1.28)\end{array}$ & $\begin{array}{l}0.0171 \\
(0.74)\end{array}$ & $\begin{array}{c}0.00536 \\
(0.24)\end{array}$ & $\begin{array}{l}0.0221 \\
(1.05)\end{array}$ & $\begin{array}{l}0.0437 \\
(1.50)\end{array}$ \\
\hline Observations & 5383 & 5383 & 5383 & 5383 & 5382 \\
\hline R-squared & 0.440 & 0.325 & 0.267 & 0.251 & 0.192 \\
\hline
\end{tabular}

$*, * *, * * *$, and $* * * *$ denote statistical significance at $10,5,1$, and 0.1 percent level, respectively. 
Panel B. Change in Performance When Funds Start to File 13F (Error Corrected)

Change in Alpha

\begin{tabular}{|c|c|c|c|c|c|}
\hline & Raw Return & Market Model & FF3 Factor & $\begin{array}{c}\text { Carhart } 4 \\
\text { Factor } \\
\end{array}$ & $\begin{array}{c}\text { Fung-Hsieh } \\
7 \text { Factor }\end{array}$ \\
\hline & $(1)$ & $(2)$ & (3) & $(4)$ & $(5)$ \\
\hline \multirow[t]{2}{*}{$1^{\text {st }}$ Year } & $-0.448 *$ & $-0.503 * *$ & $-0.705 * * *$ & $-0.799 * * * *$ & $-0.419 *$ \\
\hline & $(-1.79)$ & $(-2.57)$ & $(-3.71)$ & $(-4.42)$ & $(-2.03)$ \\
\hline \multirow[t]{2}{*}{$2^{\text {nd }}$ Year } & -0.409 & -0.328 & -0.344 & -0.322 & -0.161 \\
\hline & $(-1.72)$ & $(-1.39)$ & $(-1.65)$ & $(-1.18)$ & $(-1.04)$ \\
\hline \multirow[t]{2}{*}{$3^{\text {rd }}$ Year } & 0.0638 & -0.00522 & 0.0789 & 0.143 & 0.0821 \\
\hline & $(0.26)$ & $(-0.02)$ & $(0.35)$ & $(0.43)$ & $(0.50)$ \\
\hline \multirow[t]{2}{*}{$4^{\text {th }}$ Year } & -0.321 & -0.172 & -0.210 & -0.103 & 0.0294 \\
\hline & $(-0.92)$ & $(-0.56)$ & $(-0.70)$ & $(-0.32)$ & $(0.08)$ \\
\hline \multirow[t]{2}{*}{$5^{\text {th+ }}$ Year } & -0.335 & -0.240 & -0.433 & -0.418 & -0.253 \\
\hline & $(-1.27)$ & $(-0.94)$ & $(-1.44)$ & $(-1.33)$ & $(-0.80)$ \\
\hline $\begin{array}{l}\text { Lag Change in } \\
\text { Size }\end{array}$ & $-1.35 * * * *$ & $-1.08 * * * *$ & $-8.59 * * *$ & $-7.25 * * *$ & $-3.45 * *$ \\
\hline$\left(\mathrm{x} 10^{-10}\right)$ & $(-5.56)$ & $(-5.91)$ & $(-3.98)$ & $(-4.05)$ & $(-2.90)$ \\
\hline $\begin{array}{l}\text { Lag Change in } \\
\operatorname{Size}^{2}\end{array}$ & $7.51 * * * *$ & $6.59 * * * *$ & $5.21 * * *$ & $4.27 * * *$ & $2.48 * * *$ \\
\hline$\left(\mathrm{x} 10^{-20}\right)$ & $(5.18)$ & $(5.67)$ & $(3.72)$ & $(3.65)$ & $(3.76)$ \\
\hline \multirow[t]{2}{*}{ Constant } & 1.472 & 1.294 & 0.592 & 1.602 & 1.541 \\
\hline & $(1.07)$ & $(0.84)$ & $(0.41)$ & $(1.14)$ & $(1.03)$ \\
\hline Observations & 5382 & 5383 & 5383 & 5383 & 5382 \\
\hline R-squared & 0.237 & 0.241 & 0.199 & 0.216 & 0.140 \\
\hline
\end{tabular}


Table 7. Illiquidity and the Impact of Portfolio Disclosure on Hedge Fund Performance

This table reports the results of the following regression model:

Performance $_{i, t}=\alpha+\beta \cdot$ Disclosure $_{i, t}+\gamma_{1} \cdot$ Illiquidity $_{i} \cdot$ Disclosure $_{i, t}+\gamma_{2} \cdot$ Illiquidity $\beta_{1} \cdot \log$ Size $_{i, t-1}+\beta_{2} \cdot(\log$ Size

Illiquidity $_{i, t}$ is the Amihud (2002) illiquidity measure calculated based on the holdings disclosed in 13F. The Amihud (2002) illiquidity measure is calculated as the average daily illiquidity during the quarter preceding the $13 \mathrm{~F}$ filing quarter (where daily illiquidity is calculated as the absolute return divided by the dollar trading volume on that day):

$$
\text { Illiq }_{Q}=\frac{1}{N} \sum_{t=1}^{N} \frac{\mid \text { ret }_{t} \mid}{\text { vol }_{t} \cdot \operatorname{prc}_{t}}
$$

where $I I l i q_{Q}$ is quarterly illiquidity, $N$ is the number of days in the quarter, $r e t_{t}, v l_{t}$, and $\operatorname{prc}_{t}$ are the daily return, trading volume, and the price on day $t$, respectively.

\begin{tabular}{|c|c|c|c|c|c|}
\hline & Raw & $\begin{array}{l}\text { Alpha } \\
\text { (Market } \\
\text { Model) }\end{array}$ & $\begin{array}{c}\text { Alpha } \\
\text { (FF3 } \\
\text { Factors) } \\
\end{array}$ & $\begin{array}{c}\text { Alpha } \\
\text { (Carhart } 4 \\
\text { Factors) } \\
\end{array}$ & $\begin{array}{c}\text { Alpha } \\
\text { (FT7 } \\
\text { Factors) }\end{array}$ \\
\hline & $(1)$ & (2) & (3) & (4) & (5) \\
\hline Disclosure & $\begin{array}{c}-0.0178 \\
(-1.01) \\
- \\
0.00469 *\end{array}$ & $\begin{array}{c}-0.0283^{*} \\
(-2.22)\end{array}$ & $\begin{array}{c}-0.0332 * * \\
(-2.85)\end{array}$ & $\begin{array}{c}-0.0270 * * \\
(-2.51)\end{array}$ & $\begin{array}{c}-0.0274^{*} \\
(-2.23)\end{array}$ \\
\hline Lagged log Size & $\begin{array}{c}* * \\
(-4.07)\end{array}$ & $\begin{array}{c}-0.00347 \\
(-1.72)\end{array}$ & $\begin{array}{c}-0.00188 \\
(-0.48)\end{array}$ & $\begin{array}{c}-0.00113 \\
(-0.32)\end{array}$ & $\begin{array}{c}-0.000485 \\
(-0.14)\end{array}$ \\
\hline Lagged (log & 0.000119 & & & & \\
\hline Size $)^{2}$ & $\begin{array}{c}* * * \\
(4.21)\end{array}$ & $\begin{array}{c}0.0000900 \\
(1.86)\end{array}$ & $\begin{array}{l}0.0000511 \\
\quad(0.51)\end{array}$ & $\begin{array}{c}0.0000281 \\
(0.31)\end{array}$ & $\begin{array}{c}0.0000256 \\
(0.30)\end{array}$ \\
\hline Disclosure $\mathrm{x}$ & & & - & & \\
\hline Illiquidity & $\begin{array}{c}-0.000777 \\
(-0.97)\end{array}$ & $\begin{array}{c}-0.00126^{*} \\
(-2.07)\end{array}$ & $\begin{array}{c}0.00149 * * \\
(-2.72)\end{array}$ & $\begin{array}{c}-0.00119 * \\
(-2.34)\end{array}$ & $\begin{array}{c}-0.00126^{*} \\
(-2.17)\end{array}$ \\
\hline Illiquidity & $\begin{array}{c}0.000820 \\
(1.36) \\
0.0802 * *\end{array}$ & $\begin{array}{c}0.000998 \\
(1.86)\end{array}$ & $\begin{array}{c}0.00122 * * \\
\quad(3.43)\end{array}$ & $\begin{array}{c}0.00104 * * \\
\quad(2.68)\end{array}$ & $\begin{array}{c}0.00108 * \\
(2.27)\end{array}$ \\
\hline Constant & $\begin{array}{c}* \\
(4.02)\end{array}$ & $\begin{array}{c}0.0602 * * \\
(2.55)\end{array}$ & $\begin{array}{c}0.0525 \\
(1.38)\end{array}$ & $\begin{array}{c}0.0429 \\
(1.28)\end{array}$ & $\begin{array}{c}0.0379 \\
(1.00)\end{array}$ \\
\hline Observations & 534 & 534 & 534 & 534 & 534 \\
\hline R-squared & 0.182 & 0.053 & 0.057 & 0.060 & 0.117 \\
\hline
\end{tabular}


Table 8. The Impact of 13F Disclosure on the Correlations of Hedge Fund Returns

The regression model in the table below is:

$$
R_{i, t}^{2}=\alpha+\beta_{1} \cdot \text { Disclosure }_{i, t}+\varepsilon_{i, t}
$$

where $R_{i, t}^{2}$ is the R-squared from regressing monthly returns of fund family $i$ on the valueweighted returns of hedge funds in the same style in year $t$. Disclosure $e_{i, t}$ is a dummy variable which is equal to 1 if fund family $i$ files Form $13 \mathrm{~F}$ in year $t$, otherwise 0 . Fund fixed effects are included in the model.

\begin{tabular}{|c|c|c|c|c|}
\hline & \multicolumn{4}{|c|}{ R-squared } \\
\hline & $(1)$ & $(2)$ & (3) & $(4)$ \\
\hline Disclosure & $\begin{array}{c}0.0348 * * * \\
(2.77)\end{array}$ & $\begin{array}{c}0.0218 * \\
(1.72)\end{array}$ & $\begin{array}{c}0.0347 * * \\
(2.48)\end{array}$ & $\begin{array}{c}0.0333 * * \\
(2.35)\end{array}$ \\
\hline Lag log Size & & & $\begin{array}{c}-0.0500 * * \\
(-2.26)\end{array}$ & $\begin{array}{c}-0.0446^{* *} \\
(-2.05)\end{array}$ \\
\hline Lag $\log \operatorname{Size}^{2}$ & & & $\begin{array}{c}0.00235 * * * * \\
(3.66)\end{array}$ & $\begin{array}{c}0.00185 * * * \\
(2.93)\end{array}$ \\
\hline Constant & $\begin{array}{c}0.419 * * * * \\
(143.76)\end{array}$ & $\begin{array}{c}0.441 * * * * \\
\quad(4.11)\end{array}$ & $\begin{array}{c}0.553 * * * \\
(2.85)\end{array}$ & $\begin{array}{c}0.914 * * * \\
(3.19)\end{array}$ \\
\hline Year Dummy & No & Yes & No & Yes \\
\hline Observations & 13571 & 13571 & 11175 & 11175 \\
\hline R-squared & 0.001 & 0.077 & 0.014 & 0.068 \\
\hline
\end{tabular}


Table 9. Summary Statistics on Hedge Fund Compensation

This table provides summary statistics on hedge fund compensation schemes, including incentive fees, management fees, and whether funds use a high-water mark. Funds of funds and funds that launched after their fund family stopped filing form $13 \mathrm{~F}$ are excluded from the sample. Panel A reports and compares compensation schemes for non- $13 \mathrm{~F}$ filers and $13 \mathrm{~F}$ filers. Non-13F filers refer to funds that never filed $13 \mathrm{~F}$ during the sample period and $13 \mathrm{~F}$ filers refers to funds that belong to a fund family that filed $13 \mathrm{~F}$ at least once. Panel B reports and compares the compensation scheme for funds that launched before their fund families started to file $13 \mathrm{~F}$ and for funds that launched during the period that their fund families filed $13 \mathrm{~F}$.

Panel A. Non-13 Filers and 13F Filers

\begin{tabular}{|c|c|c|c|c|c|c|c|c|c|c|c|c|c|}
\hline \multirow[b]{3}{*}{ Incentive Fee (\%) } & \multicolumn{6}{|c|}{ Non-13F Filers } & \multicolumn{6}{|c|}{ 13F Filers } & \multirow{2}{*}{$\begin{array}{c}\text { Difference } \\
13 \mathrm{~F}- \\
\text { Non13F }\end{array}$} \\
\hline & $\mathrm{N}$ & Mean & p50 & $\mathrm{Sd}$ & Min & $\operatorname{Max}$ & $\mathrm{N}$ & Mean & $\mathrm{p} 50$ & $\mathrm{Sd}$ & Min & $\operatorname{Max}$ & \\
\hline & 6248 & 18.16 & 20 & 5.89 & 0 & 50 & 450 & 18.92 & 20 & 4.20 & 0 & 25 & $0.76 * * *$ \\
\hline Management Fee (\%) & 6254 & 1.50 & 1.5 & 0.66 & 0 & 10 & 450 & 1.50 & 1.5 & 0.61 & 0 & 4 & 0.00 \\
\hline High-Water Mark & 6254 & 0.67 & 1 & 0.47 & 0 & 1 & 450 & 0.84 & 1 & 0.37 & 0 & 1 & $0.17 * * * *$ \\
\hline Lockup Dummy & 6265 & 0.25 & 0 & 0.43 & 0 & 1 & 451 & 0.42 & 0 & 0.49 & 0 & 1 & $0.17 * * * *$ \\
\hline $\begin{array}{l}\text { Family Assets } \\
\text { (\$ million) }\end{array}$ & 4968 & 209 & 0 & 672 & 0 & 20134 & 405 & 526 & 137 & 1000 & 0 & 5775 & $316 * * * *$ \\
\hline Family Age (month) & 6012 & 33 & 9 & 48 & 1 & 353 & 442 & 59 & 46 & 54 & 1 & 183 & $26 * * * *$ \\
\hline
\end{tabular}

Panel B. Before and During 13F Filing

\begin{tabular}{|c|c|c|c|c|c|c|c|c|c|c|c|c|c|}
\hline & \multicolumn{6}{|c|}{ Launched Before 13F Filing } & \multicolumn{6}{|c|}{ Launched During 13F Filing } & \multirow{2}{*}{$\begin{array}{c}\text { Difference } \\
\text { During- } \\
\text { Before }\end{array}$} \\
\hline & $\mathrm{N}$ & Mean & p50 & $\mathrm{Sd}$ & Min & Max & $\mathrm{N}$ & Mean & $\mathrm{p} 50$ & $\mathrm{Sd}$ & Min & $\operatorname{Max}$ & \\
\hline Incentive Fee $(\%)$ & 208 & 18.61 & 20 & 4.49 & 0 & 25 & 242 & 19.18 & 20 & 3.93 & 0 & 25 & 0.56 \\
\hline Management Fee (\%) & 208 & 1.49 & 1.5 & 0.66 & 0 & 4 & 242 & 1.50 & 1.5 & 0.56 & 0 & 4 & 0.01 \\
\hline High-Water Mark & 208 & 0.77 & 1 & 0.42 & 0 & 1 & 242 & 0.90 & 1 & 0.30 & 0 & 1 & $0.13 * * * *$ \\
\hline Lockup Dummy & 208 & 0.40 & 0 & 0.49 & 0 & 1 & 243 & 0.44 & 0 & 0.50 & 0 & 1 & 0.04 \\
\hline $\begin{array}{l}\text { Family } \\
\text { Assets }(\$ \text { million })\end{array}$ & 178 & 390 & 25 & 1031 & 0 & 5580 & 227 & 632 & 272 & 963 & 0 & 5775 & 242 \\
\hline Age (month) & 202 & 40 & 24 & 46 & 1 & 167 & 240 & 75 & 73 & 55 & 1 & 183 & 35 \\
\hline
\end{tabular}


Table 10. The Impact of 13F Disclosure on Hedge Fund Compensation Schemes

This table reports the results of regressing hedge fund incentive fee on variable Disclosure $_{i}$ that indicates whether its fund family files $13 \mathrm{~F}$ disclosure at fund $i$ 's inception. Control variables include assets under management and the age of fund family at fund $i$ 's inception. Fund's investment style, fund family, and inception year fixed effects are included in the model and errors are clustered.

\begin{tabular}{|c|c|c|c|c|c|}
\hline \multirow[b]{3}{*}{ Disclosure } & \multicolumn{5}{|c|}{ Incentive Fees } \\
\hline & $(1)$ & $(2)$ & (3) & $(4)$ & $(5)$ \\
\hline & $\begin{array}{l}1.169^{*} \\
(1.91)\end{array}$ & $\begin{array}{l}1.097^{*} \\
(1.84)\end{array}$ & $\begin{array}{c}1.164 * * \\
(2.65)\end{array}$ & $\begin{array}{c}1.159 * * \\
(2.66)\end{array}$ & $\begin{array}{c}0.996 * \\
(1.69)\end{array}$ \\
\hline log Family Assets & & & $\begin{array}{c}-0.00979 \\
(-0.10)\end{array}$ & $\begin{array}{c}-0.152 * * \\
(-2.46)\end{array}$ & $\begin{array}{c}0.0457 \\
(0.56)\end{array}$ \\
\hline log Family Age & & & $\begin{array}{c}-0.212 * * \\
(-2.41)\end{array}$ & & $\begin{array}{l}-0.152 \\
(-1.03)\end{array}$ \\
\hline Constant & $\begin{array}{c}21.14 * * * * \\
(116.69)\end{array}$ & $\begin{array}{c}19.17 * * * * \\
(20.80)\end{array}$ & $\begin{array}{c}-1.574 * * \\
(-2.51)\end{array}$ & $\begin{array}{c}-1.475 * * \\
(-2.45)\end{array}$ & $\begin{array}{c}14.54 * * * * \\
(12.56)\end{array}$ \\
\hline Fund Style Dummy & No & Yes & Yes & Yes & Yes \\
\hline Fund Family Dummy & Yes & Yes & No & No & Yes \\
\hline Inception Year Dummy & Yes & Yes & Yes & Yes & Yes \\
\hline Observations & 6698 & 6698 & 5359 & 5360 & 5359 \\
\hline R-squared & 0.031 & 0.038 & 0.069 & 0.068 & 0.043 \\
\hline
\end{tabular}


Table 11.The Impact of 13F Disclosure on Fund Flows

Panel A of this table reports the summary statistics and univariate tests of flows 1) for the $13 \mathrm{~F}$ filers and the non-13F filers, and 2) for the $13 \mathrm{~F}$ filers in the period before they began filing form $13 \mathrm{~F}$ and in the period during which they filed form $13 \mathrm{~F}$.

Panel B reports the results of the panel regression below:

Flow $_{i, t}=\alpha+\beta \cdot$ Disclosure $_{i, t}+\gamma \cdot$ Controls $_{i, t-1}$

Where Flow $_{i, t}=\frac{\text { Assets Under Management }_{i, t}-\text { Assets Under Management }_{i, t-1} \cdot \operatorname{Re} \text { turn }_{i, t}}{\text { Assets Under Management }}$

Flow $_{i, t}$ is the flow in or out of investment company $i$ during year $t$, defined as the formula above. Disclosure $_{i, t}$ is equal to 1 if investment company $i$ files a 13F disclosure in year $t$. Control variables include lagged performance, lagged volatility of fund returns, lagged assets under management in log form, a lockup dummy indicating whether funds utilize lockup provisions, and a $13 F$ Filing Funds Dummy indicating whether the investment company $i$ has ever filed 13F in the sample period. Model (1) to (5) differs in how lagged performance is measured. Year fixed effects are included and errors are clustered at the investment company level.

Panel A. Univariate test on Fund Flows

\begin{tabular}{|c|c|c|c|c|c|c|c|c|}
\hline \multicolumn{4}{|c|}{ Non-13F Filers } & \multicolumn{4}{|c|}{ 13F Filers } & \multirow{2}{*}{$\frac{\text { Difference }}{13 \mathrm{~F}-\text { Non } 13 \mathrm{~F}}$} \\
\hline $\mathrm{n}$ & mean & median & sd & $\mathrm{n}$ & mean & median & sd & \\
\hline 2058 & 0.056 & 0.017 & 0.323 & 296 & 0.132 & 0.112 & 0.284 & $0.077 \quad * * * *$ \\
\hline \multicolumn{4}{|c|}{ Before 13F Filing } & \multicolumn{4}{|c|}{ During 13F Filing } & Difference \\
\hline $\mathrm{n}$ & mean & median & sd & $\mathrm{n}$ & mean & median & $\mathrm{sd}$ & 13F-Non13F \\
\hline 157 & 0.361 & 0.36 & 0.437 & 285 & 0.028 & -0.01 & 0.313 & $-0.332 \quad * * * *$ \\
\hline
\end{tabular}

$*, * *, * * *$, and $* * * *$ denote statistical significance at $10,5,1$, and 0.1 percent level, respectively. 
Panel B. The Impact of 13F Disclosure on Fund Flows

\begin{tabular}{|c|c|c|c|c|c|}
\hline & \multicolumn{5}{|c|}{ Control variable "Lag Performance" is measured by } \\
\hline & & Alpha & Alpha & Alpha & Alpha \\
\hline & Raw & (Market Model) & (FF3 Factors) & (Carhart 4 Factors) & (FT7 Factors) \\
\hline & (1) & (2) & (3) & (4) & (5) \\
\hline \multirow[t]{2}{*}{ Disclosure } & $-0.0998 * * *$ & $-0.0963 * * *$ & $-0.102 * * *$ & $-0.102 * * *$ & $-0.118 * * *$ \\
\hline & $(-2.74)$ & $(-2.62)$ & $(-2.71)$ & $(-2.71)$ & $(-3.12)$ \\
\hline \multicolumn{6}{|l|}{ Lag } \\
\hline \multirow[t]{2}{*}{ Performance } & $8.743 * * * *$ & $10.09 * * * *$ & $5.316^{* * * * *}$ & $4.836^{* * * *}$ & $1.120^{* * * *}$ \\
\hline & (7.09) & $(7.13)$ & $(3.46)$ & $(3.78)$ & $(2.96)$ \\
\hline \multirow[t]{2}{*}{ Lag Size } & $-0.0332 * * * *$ & $-0.0323 * * * *$ & $-0.0283 * * *$ & $-0.0270 * * *$ & $-0.0249 * * *$ \\
\hline & $(-3.72)$ & $(-3.65)$ & $(-3.27)$ & $(-3.12)$ & $(-2.89)$ \\
\hline \multirow[t]{2}{*}{ Lag Volatility } & $-2.057 * * *$ & $-2.080 * * *$ & $-1.801 * *$ & $-1.680 * *$ & $-1.896^{* *}$ \\
\hline & $(-3.03)$ & $(-2.97)$ & $(-2.31)$ & $(-2.25)$ & $(-2.53)$ \\
\hline \multicolumn{6}{|l|}{ Fund Family } \\
\hline \multirow[t]{2}{*}{ Age } & $-0.0285 * * * *$ & $-0.0275^{* * * * *}$ & $-0.0267 * * * *$ & $-0.0273 * * * *$ & $-0.0284 * * * *$ \\
\hline & $(-5.13)$ & $(-5.04)$ & $(-4.71)$ & $(-4.83)$ & $(-4.91)$ \\
\hline \multirow[t]{2}{*}{ Lockup } & -0.00620 & -0.00818 & -0.00404 & -0.00186 & -0.00175 \\
\hline & $(-0.20)$ & $(-0.27)$ & $(-0.13)$ & $(-0.06)$ & $(-0.05)$ \\
\hline \multirow[t]{2}{*}{ Constant } & $1.032^{* * * * *}$ & $1.091 * * * *$ & $1.048 * * * *$ & $1.029 * * * *$ & $1.021 * * * *$ \\
\hline & $(5.03)$ & $(5.24)$ & $(4.96)$ & (4.86) & $(4.73)$ \\
\hline Observations & 1254 & 1254 & 1254 & 1254 & 1254 \\
\hline$\underline{\mathrm{R} \text {-squared }}$ & 0.190 & 0.188 & 0.155 & 0.152 & 0.137 \\
\hline
\end{tabular}




\section{REFERENCES}

Agarwal, Vikas, Wei Jiang, Yuehua Tang, and Baozhong Yang, 2009, Do institutional investors have an ace up their sleeves?--Evidence from confidential filings of portfolio holdings. Working paper, Georgia State University and Columbia University.

Angrist, Joshua and Jorn-Steffen Pischke, 2008, Mostly Harmless Econometrics: An Empiricist's Companion, Chapter 6: Getting a Little Jumpy: Regression Discontinuity Designs. Princeton, NJ: Princeton University Press.

Aragon, George, Michael Hertzel, and Zhen Shi, 2009, Why do hedge funds avoid disclosure? Evidence from confidential 13F filings. Working paper, Arizona State University.

Amihud, Yakov, 2002, Illiquidity and stock returns: cross-section and time-series effects, Journal of Financial Markets 5, 31-56.

Berk, Jonathan and Richard Green, 2004, Mutual fund flows and performance in rational markets, The Journal of Political Economy, 112, 1269-1295.

Coles, Jeffrey, Daveen Daniel, and Lalitha Naveen, 2006, Managerial incentives and risk-taking, Journal of Financial Economics, 79, 431-468.

Frank, Mary M., James M. Poterba, Douglas A. Shackelford, and John B. Shoven, 2004, Copycat funds: Information disclosure regulation and the returns to active management in the mutual fund industry, Journal of Law and Economics 47, 515-541.

Ge, Weili and Lu Zheng, 2006, The frequency of mutual fund portfolio disclosure, Working paper, University of Michigan.

George, Thomas J. and Chuan-Yang Hwang, 2007, Disclosure policies of investment companies, Working paper, University of Houston.

Golec, Joseph and Laura Starks, 2004, Performance fee contract change and mutual fund risk, Journal of Financial Economics 73, 93-118.

Grinblatt, Mark and Sheridan Titman, 1989, Portfolio performance evaluation: Old issues and new insights, The Review of Financial Studies 2, 393-416

Healy, Paul M., and Krishna G. Palepu, 2001, Information asymmetry, corporate disclosure, and the capital markets: a review of the empirical disclosure literature, Journal of Accounting and Economics 31, 405-440. 
John, Kose, Hamid Mehran, and Yiming Qian, 2008, Outside Monitoring and CEO Compensation in the Banking Industry, Working paper, New York University.

Stark, Laura, 1987, Performance incentive fees: an agency theoretic approach, Journal of Financial and Quantitative Analysis, 22, 17-32.

Stulz, René, 2007, Hedge Funds: Past, Present and Future, Journal of Economic Perspectives 21 (2), 175-194.

Verrecchia, Robert E., 1983, Discretionary disclosure, Journal of Accounting and Economics 5, 365-380.

Wermers, Russ, 2001, The potential effects of more frequent portfolio disclosure on mutual fund performance, Investment Company Institute Perspective, June. 